
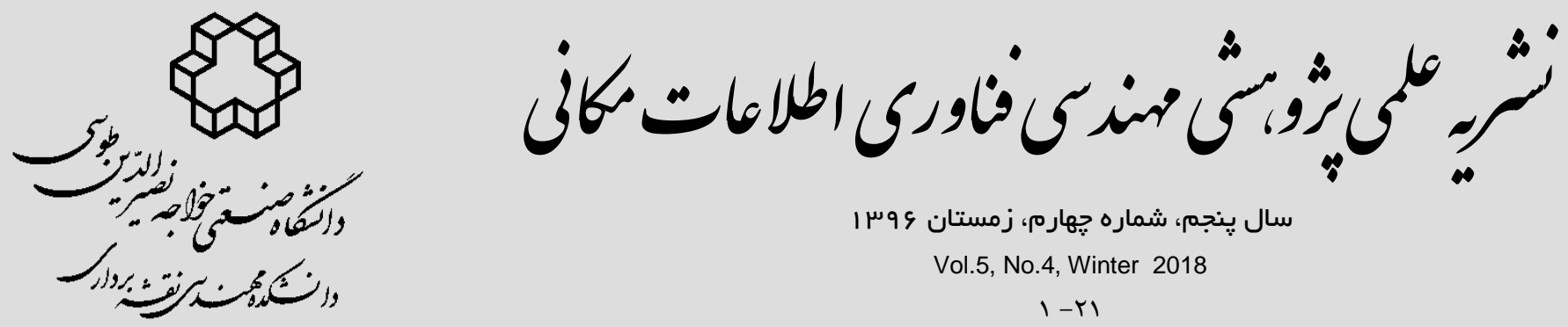

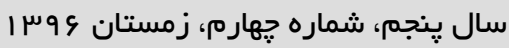
Vol.5, No.4, Winter 2018

$|-r|$

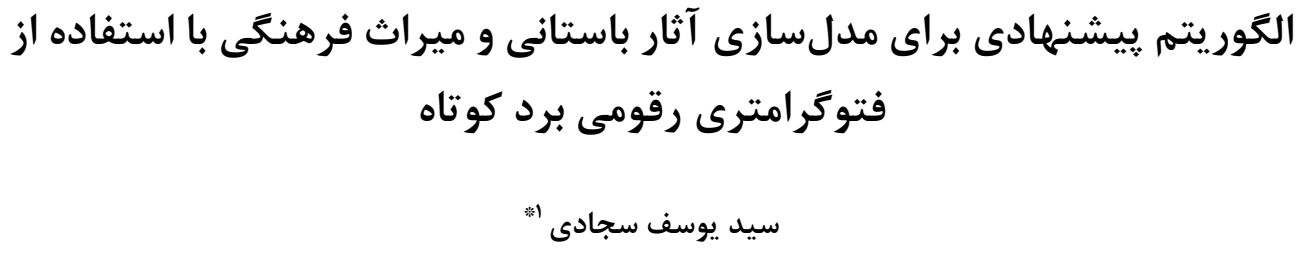

1- استاديار دانشكده نقشهبردارى دانشگاه تفرش

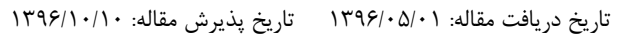

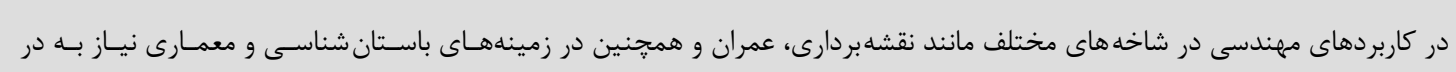

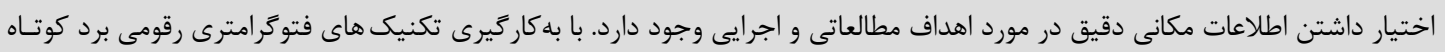

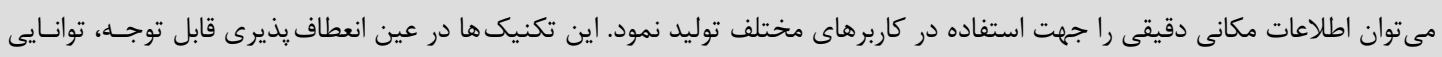

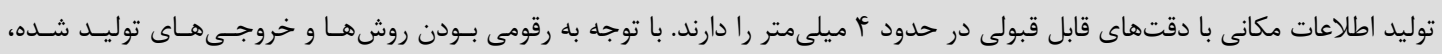

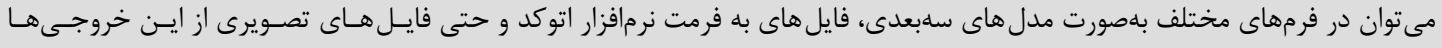

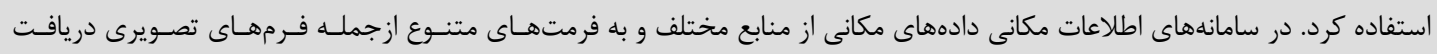

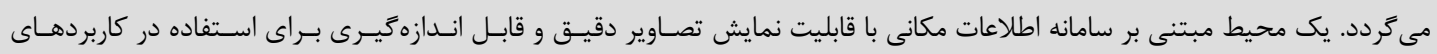

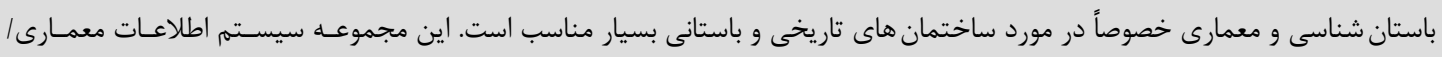

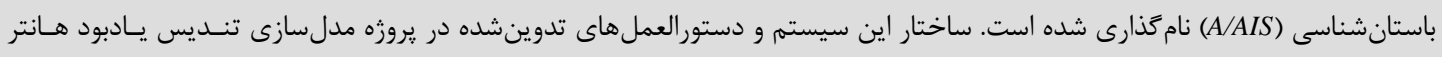

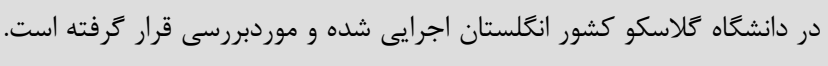

كليد وازمها : مدل سازى سلبعدى، فتوكرامترى رقومى، سامانه اطلاعات مكانى، اتوكد، (A / AIS) 
مشروط بر آنكه به دو هدف مشخص زير، دست يابد؛ | - ايجاد مدلهاى رقومى از اشياء و اجسام باستانى و ميراث فرهنكى كه امكان تجزيهوتحليل در محيط راشته باشند؛ r- تعيين محتواى دادههاى رقومى مــورد نيـاز بــراى

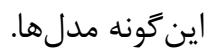

در اين مقاله به ارائه تحقيق انجامشده در زمينه باستانشناسى و معمارى مى يردازيم. اين روش در يك بـ بـ يروزه تحقيقاتى انجامشده است و در سالهائى مهاى اخير مورد توجه محققين قرار گرفته است. در اين روش راهحلى مبتنى بر تكنولوزى و با بهكارگيرى روش

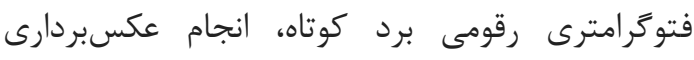
زمينى برد كوتاه و استفاده از نرمافزار اتوكد است. اين روش كه يكى سيستم ذخيرهسازى اطلاعات خروجى فتوگرامترى در سامانه اطلاعات مكانى است،

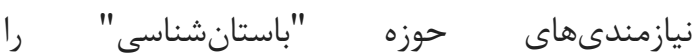
برآورده مينمايد.

يكى از مزاياى سيستمم يِيشنهادى اين است كه مى توان

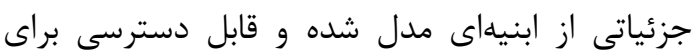

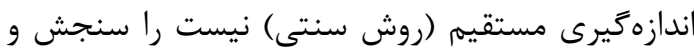
بررسى نمود. بلهبيانديگر، اين تكنيك قادر است

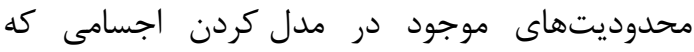

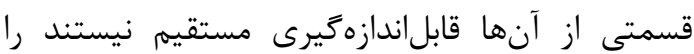
برطرف سازد. اين روش در يروزه نمونه انجام شده در

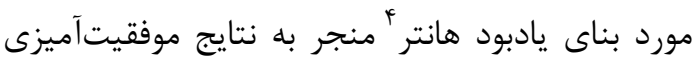
شده است.

\footnotetext{
${ }^{4}$ Hunter Memorial
}

1- مقدمه مقاله حاضر، مطالعه و تحقيقى است براى امكانسـنجى ايجاد يك سيستم اطلاعات باسـتانشناسـى - معمـارى

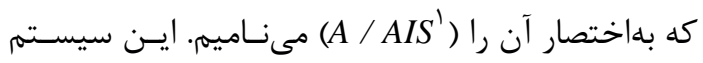

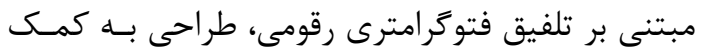
كامييوتر (

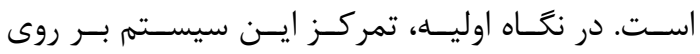

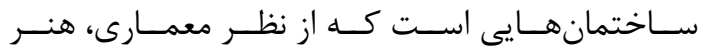
محسوب گثته و ميراث فرهنَى مىباشند. اما در نخـاه ثانويه، بايد دانست كه اشياء مختلف دنياى واقعى مانــد اتومبيل، يل ها، انواع سازهها، قطعات مكانيكى، اندامهاى انسان و بسيارى از اجسام ديخر نيز با توجـهـ بـه فراخيــر بودن سيستم يريشـنهادى، مسى توانـــد مــورد توصـيف و

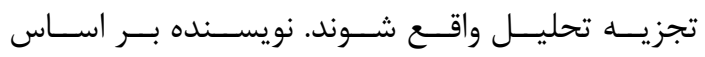
يروهشهاى متعددى كه انجام داده، معتقـد اسـت كـهـ عـلاوه بـر مسـتندنغارى و مـدلســازى اجسـام و آثـار باستانى، اين سيستم قـادر اسـت ضـمن تهيـهـ مــدل از اجسام، آنها را ي يشايشٍ إيش از خطراتى كه در كمين آنها مى باشند، ولى هنوز مشهود نيستند مطلع كند. بهعنوان نمونه اگر از اين سيستم توسط يزشكان باتجربه استفاده

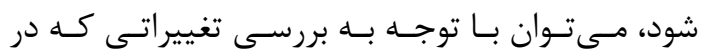
سلول هاى اندامهاى انسان رخ مى دهد و با بهره گيرى از يك سيستم هوشمند كه به اين تغييرات حساس است، از وجود بيمارى (بهخصوص انواع سرطانها) مطلع شده و سيس از بيشـرفت بيمـارى جلـو گيرى نمـود. فراخيـر

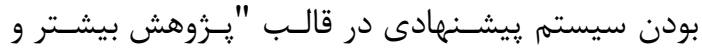

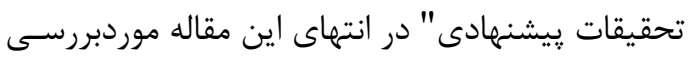

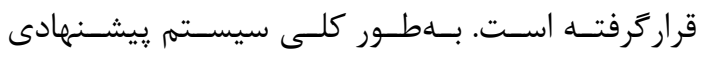
(A/AIS)

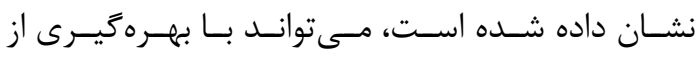
علم زئوماتيك كمك هــاى فراوانـى بــه بشـريت بنمايسد

\footnotetext{
${ }^{1}$ Archaeological and Architectural System

${ }^{2}$ Computer Aided Design

${ }^{3}$ Geospatial Information System
} 


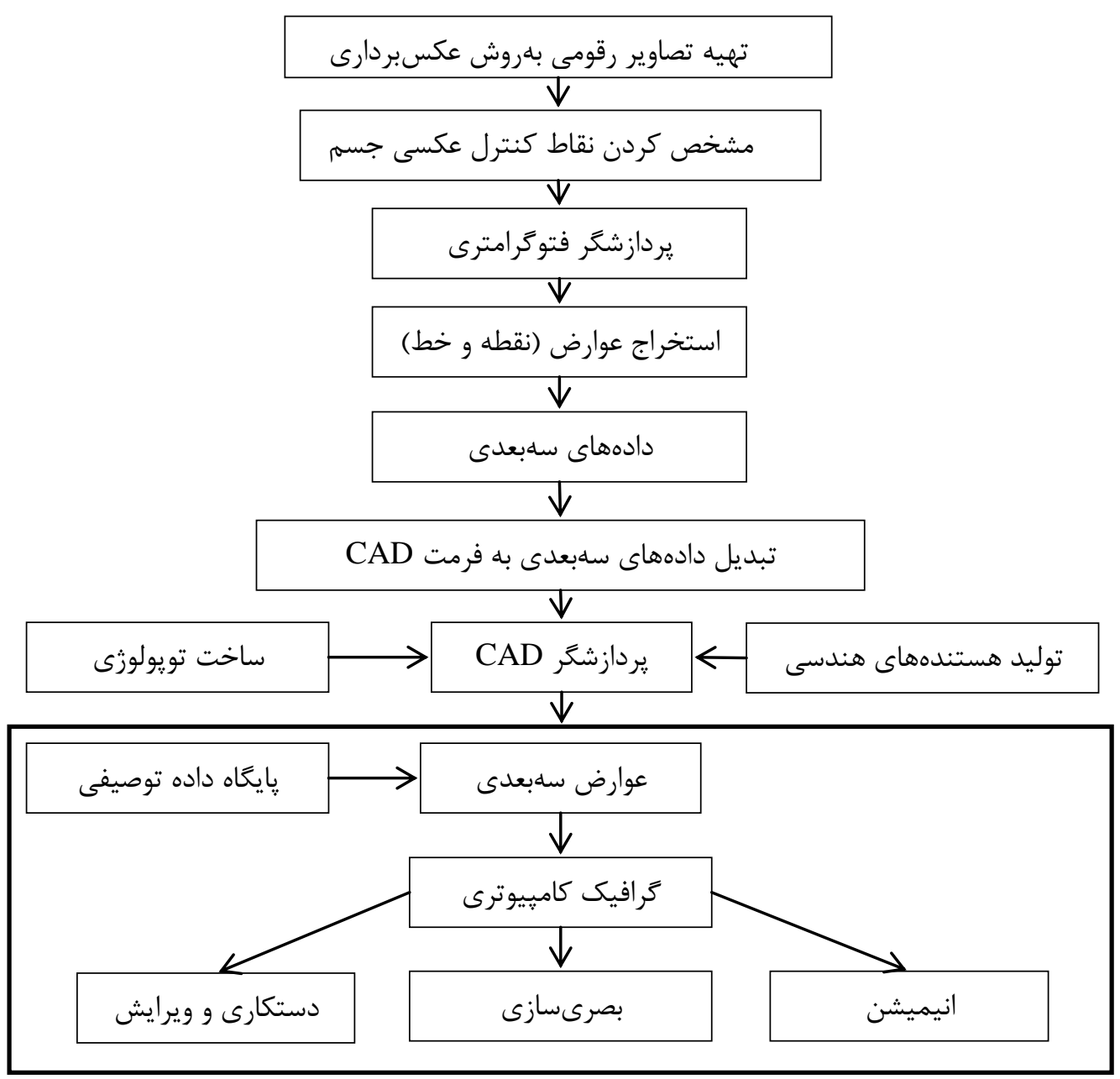

شكل ا: الكوريته ريشنههادى براى سيستم باستانشناسى / معمارى (A/AIS)

مىتواند مبناى احياى آثار باستانى قرار كيرد. يكى از

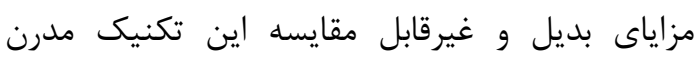

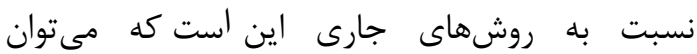

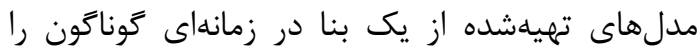

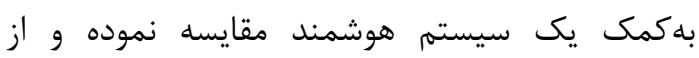
حادثهى كه در شرف تكوين بوده و با خشم معمولى قابلرؤيت نيست ولى مىرود تا موجبات آسيبرسانى نداني

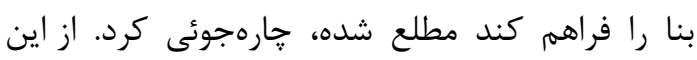

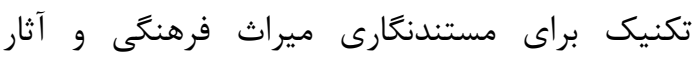
باستانى نيز استفاده مىشود.

ץ- بررسى يروزه مدلسازى به كمك فتــوَرامترى

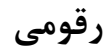

تصاوير عكسبردارى شده با دوربينهاى رقومى، با

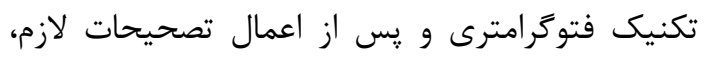

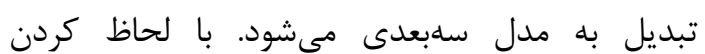
مقياس، مىتوان تمام اجزاء ابنيه واقعى را از مدل

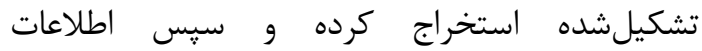
بلدستآمده را در فضاى اتوكد وارد نموده و به اهداف مورد نظر رسيد. همجنين مدل توليد شده درمواقعى كه

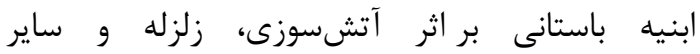

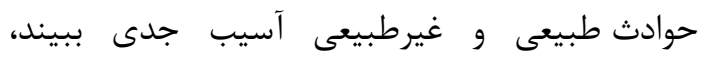


نوارى از اجزاى اين بنا مورد نياز است (نقشهبردارى

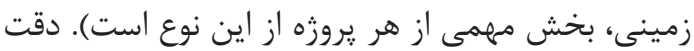
بهدستآمده بادر نظر كرفتن ديكر فاصلههاى از ابعاد اثر، بلطور قابلتوجهى با دقت مورد انتظار مطابقت دارد (ييشنهاد أ • سانتيمتر براى جذر ميانكَين مربع خطا مىباشد، ولى مقدار بهدستآهده ^^ץ • سانتيمتر است). شكل (ז) نيمرخ شمالى از يادبود هانتر را نشان مى دهد كه جند اندازمخيرى با متر انوار به دليل ذكرشده به آنها اين شكل افزودهشه است. مدال يرتره از برادران هانتر را مىتوان در نماى شمالى اين بناى يادبود مشاهده كرد. ويليام و جان هانتر نان نام خود ران را بهعنوان

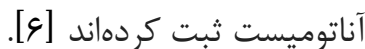

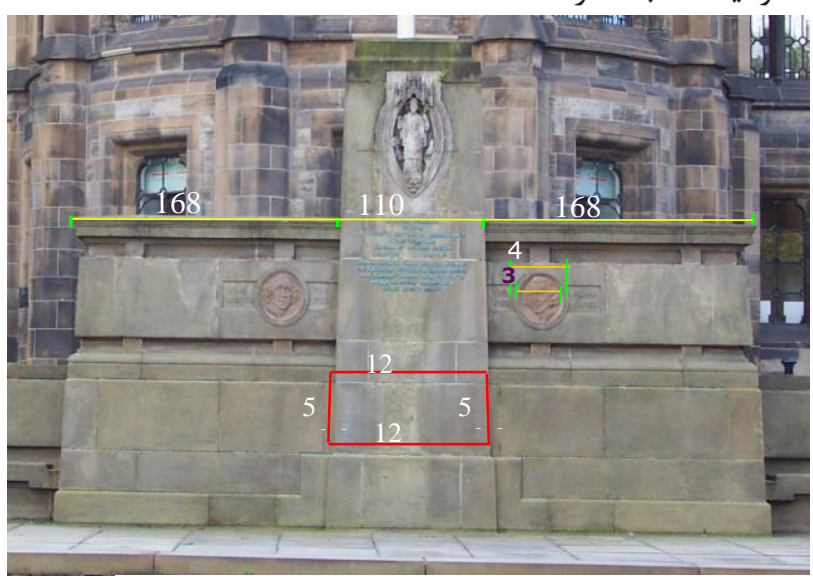

شكل r: نماى شمالى از مجسمه يادبود هانتر با مقياس •ه:

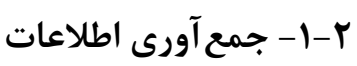

در اين يزوهش، براى به دست آوردن تصاوير با اطلاعات

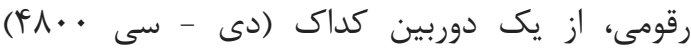

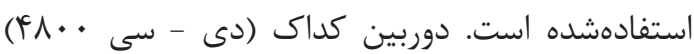
يك دوربين ترانقيمت نيست، اما استفاده از اين دوربين مىتواند رزولوشنهاى مختلفى را براى تصاوير

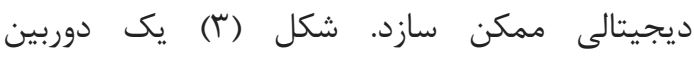

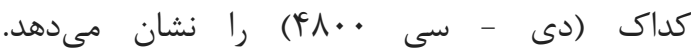
مشخصات اين دوربين بهشرح زير است:

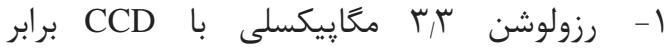

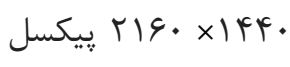

مدلسازى موفق يك اثر باستانى زمانى انجام مىشود

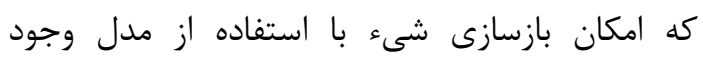
داشته باشد. استفاده از روش فتوكرامترى رقومى منجر

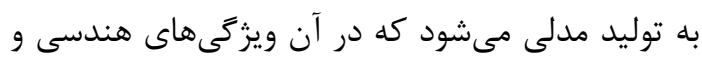
تصويرى (بافتى) ساختمان قابل بازيابى است. اطلاعات مرتبط شامل اطلاعات توصيفى عارضه با ايجاد ابرييوند' قابل اتصال به مدل توليد شده است.

در سيستمهاى كد (CAD) نظير اتوكد، امكان ترسيم و توليد مدلهاى سلبعدى در عين بهكاركيرى ساده

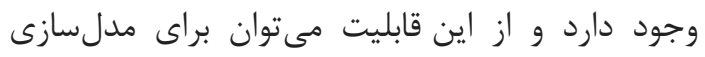

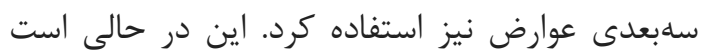

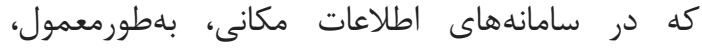

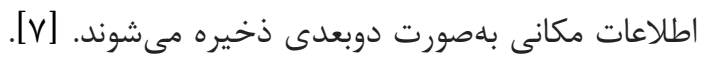

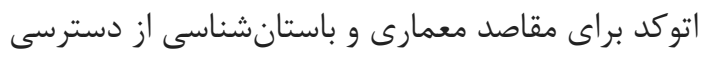

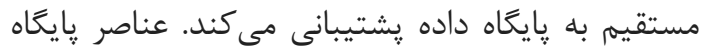
داده مى توانند با دادههاى كرافيكى مثل تصاوير رسترى بادي و اطلاعات متنى تركيب شوند. خروجى نقاط رقان رقومى مادى مىتواند بهطور مستقيم در اتوكد وارد شود. با استفاده از فتوخرامترى رقومى برد كوتاه مىتوان ويزگكىهاى

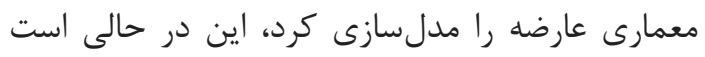
كه ديخر روشهاى مدلسازى اثر معمارى، نياز بهاندازه، شكل و مكان ويزگى هاى ازدسترفته آن دارد.

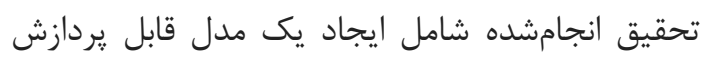

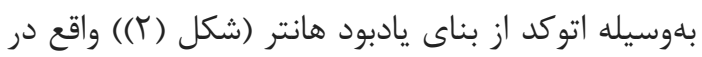
ورودى درب دانشگاه كلاسكو است. اين مجسمه در النادئ

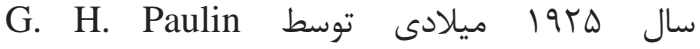

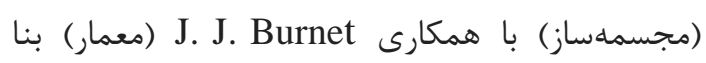
كرديده است. با استفاده از فتوكرامترى رقومى، بازسازى عناصر معمارى در كامييوتر و ذخيره ساير مشخصات مجسمه يادبود مذكور مقدور مى گردد. همجنين براي

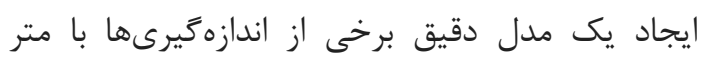

\footnotetext{
${ }^{1}$ Hyperlink

${ }^{2}$ Computer Aided Design
} 
با توجه به تصاوير رقومى متعددى كه از قسمتهاى

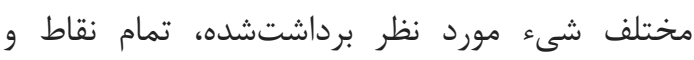

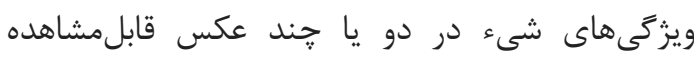
هستند. به همين دليل موقعيت عكسبردارى بايد مورد

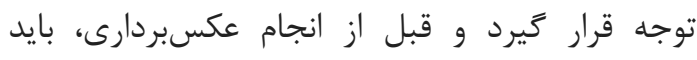
عكاسى و اندازمخيرىها را برنامهريزى كرد. تعداد 9 عكس ديجيتالى از يروزه يادبود هانتر اخذ و ذخيره شد.

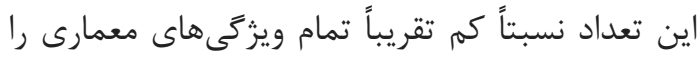

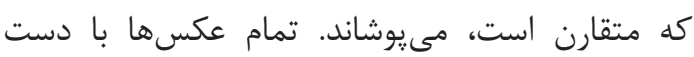
(بدون استفاده از سهيايه) گرفتهشدند، اما محورهاى تمائ

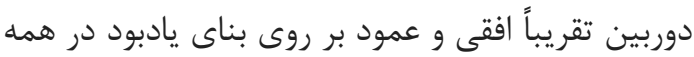

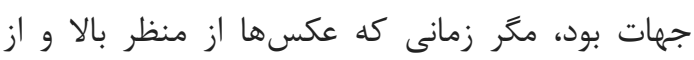

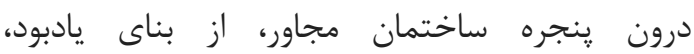

$$
\text { كرفته شد. }
$$

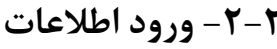

مــدلســازى مجسـمه يـادبود هــانتر بــا اسـتفاده از

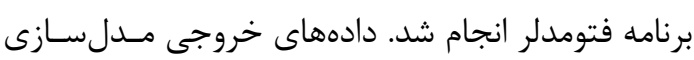

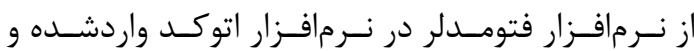

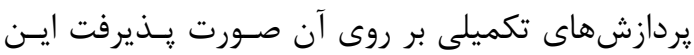

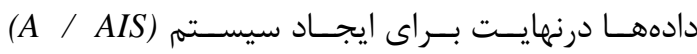

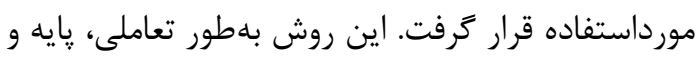
مبناى هندسى الخَـوريتم (A / AIS) را ايجـاد مسى كنــد.

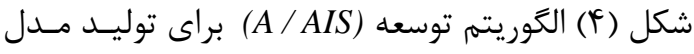

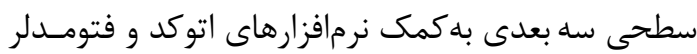
را نشان مى دهد. لازم به ذكر است كه بسيارى از اشـياء

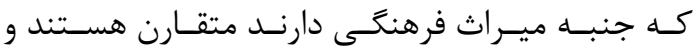

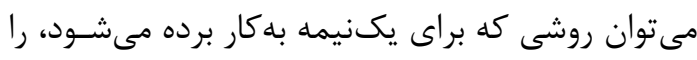

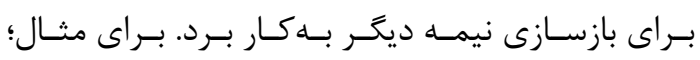
از انتهاى قسمت غربى يك ساختمان، بخشى را انتخاب

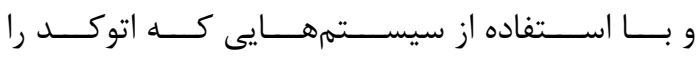

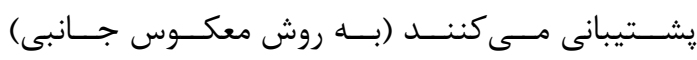

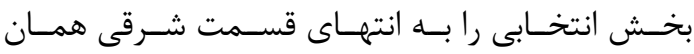

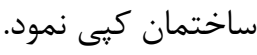

r- صفحهنمايش // اينجى LCD و منظره ياب تصوير واقعى r- زوم ץ برابر، لنز

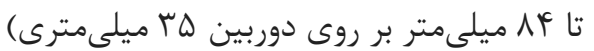

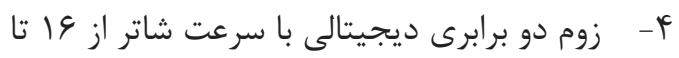
يك هزارم ثانيه

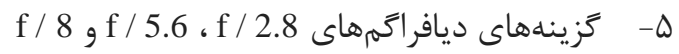

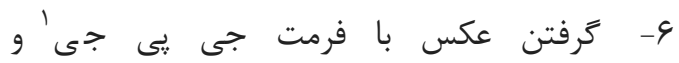

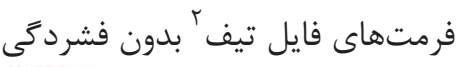

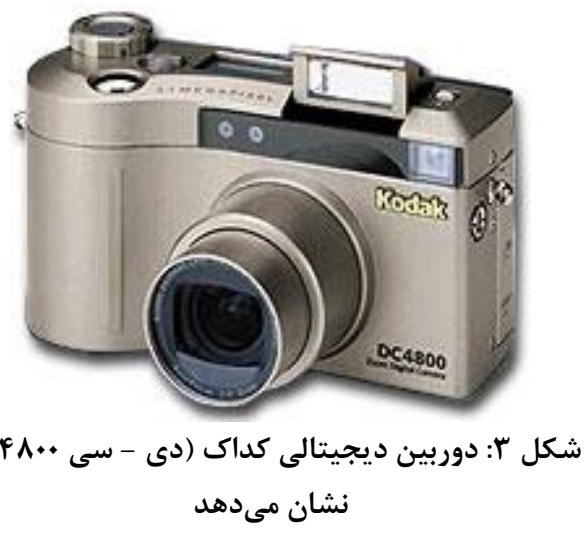

در اين يروزه، فتوكرامترى رقومى برد كوتاه با هدف

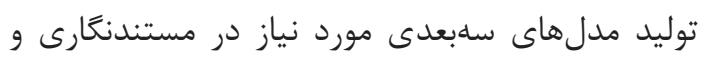
طراحى كامييوترى در يك سيستم (A / AIS)

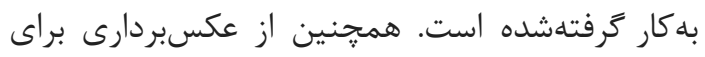

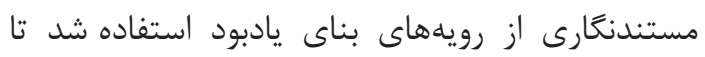

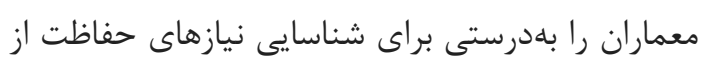

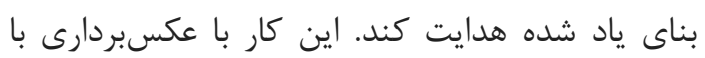
مقياس تقريبى •ه : إبراى تمام ويزّكى هاى مورد نظر

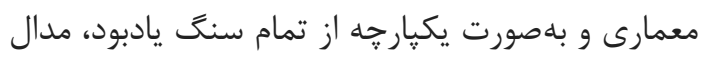

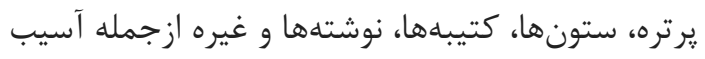

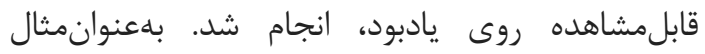

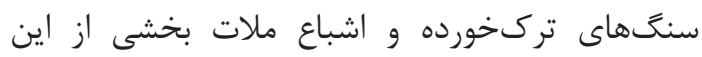

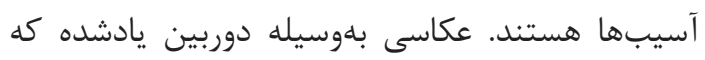
در اطراف شىء مورد نظر مستقر شده بود، انجام شد. 


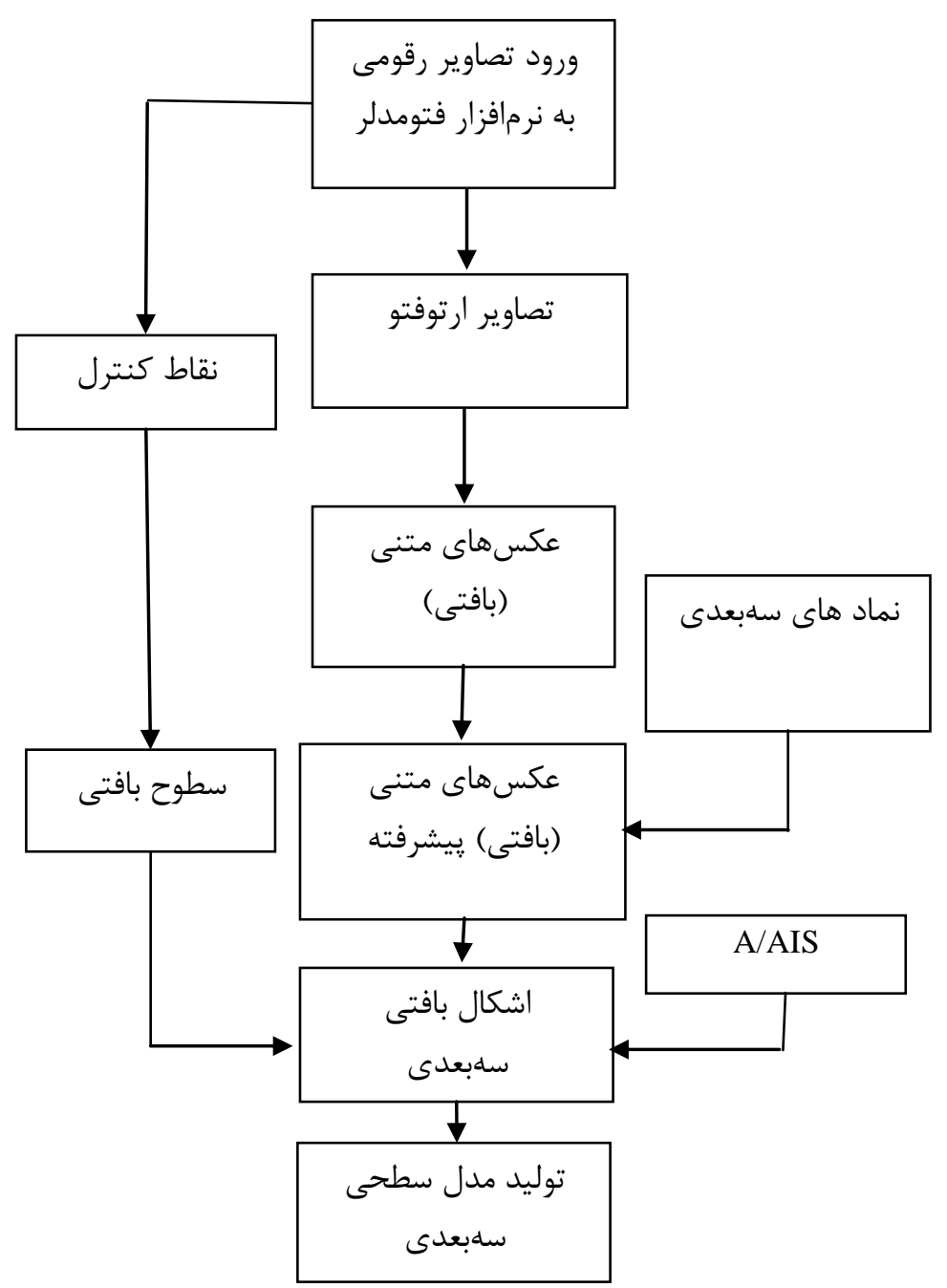

شكل f : الكوريتم توسعه (AIS / براى توليد مدل سطحى سهبعدى بهكمى نرمافزارهاى اتوكد و فتومدلر را نشان مىدهد

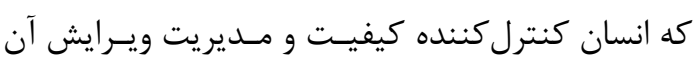

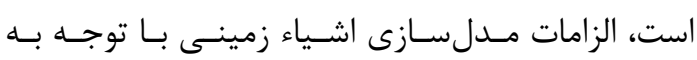

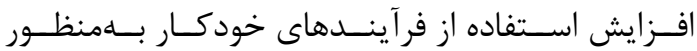
مدلسازى سطحى قابل اندازهگيرى، به ابزارهايى بـراى

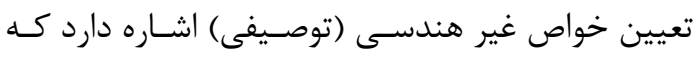

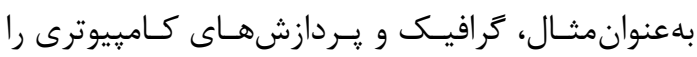
مىتوان نام برد. كرافيك كامبيوترى قادر است تا تصاوير

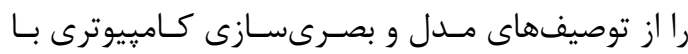

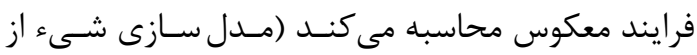

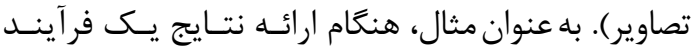

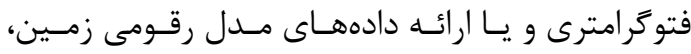

r-r- يردازش اطلاعات و تصاوير

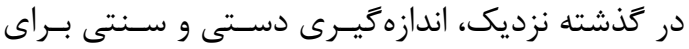

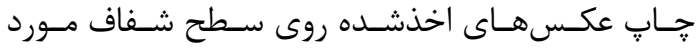

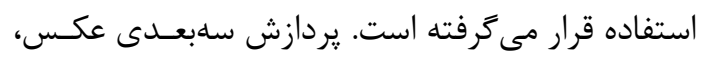

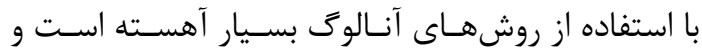
قابليت استخر اج اطلاعات كمى داشـته و داراى كـاربرد

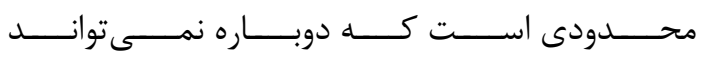
موردبررسى قرار كيـــد. عـلاوه بــرآن، ايـن روش بسـيار وقت كيربوده و نياز به حضور شخص متخصص دارد.

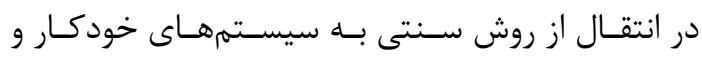
كامييوترى براى ايجاد مدل سهبعدى از سطوح اجسـام 
كـه مكـان نقــاط و لبــهـــا را در فضـاى ســبعـدى

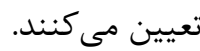
يس از مشخص كردن و علامت كذارى حداقل سـه زوج

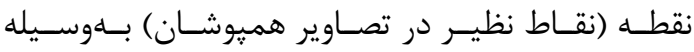

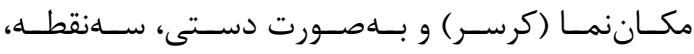

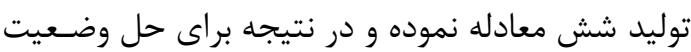

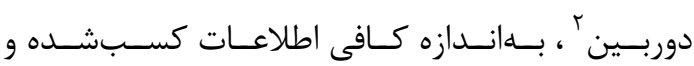
شناسايى مابقى نقاط بهصورت خودكار انجام مسىشـود.

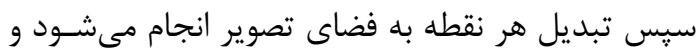

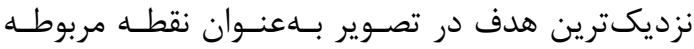

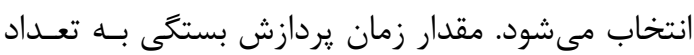

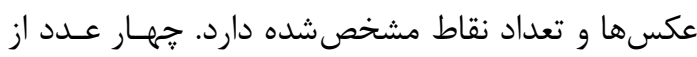
بهترين عكسها براى ايجاد مدل سهبعدى در اين بروزه

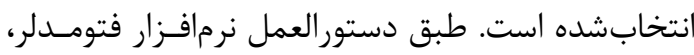

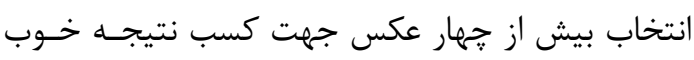

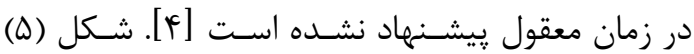
جهار عكس انتخـابى بـراى يـردازش توسـط نـرمافزرار فتومدلر در يك تنظيم را نشان مى دهد.

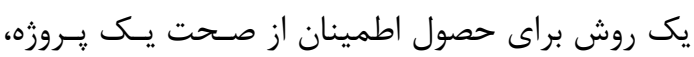

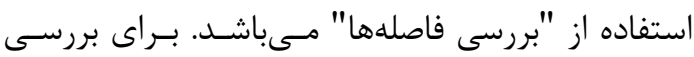

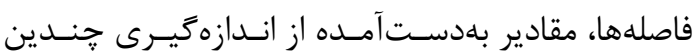

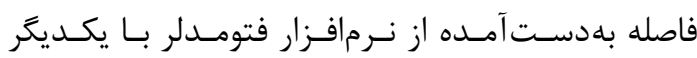

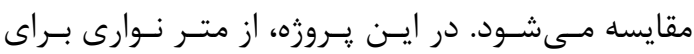

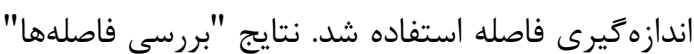

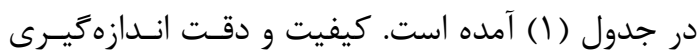

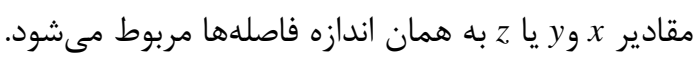

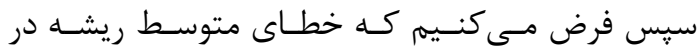

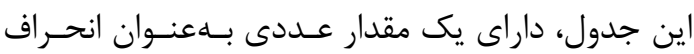

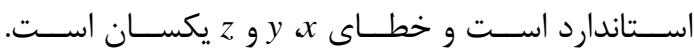
مطـابق تئسـورى خطاهــا (انتشــار واريــانس)، خطــاى مختصات استاندارد

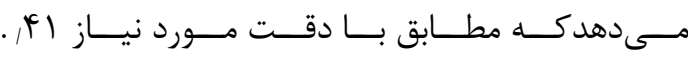

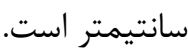

${ }^{2}$ Camera Orientation
احر اين فرآيندها در نزديكى نرمافزار در دسترس باشند،

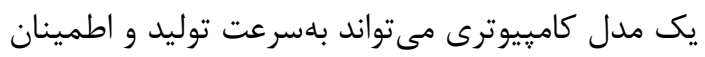

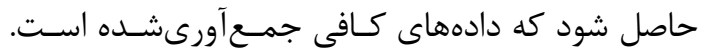

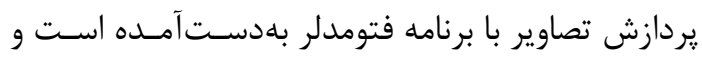
ايجاد مدلهاى سهبعدى با اتصال نقاط سهبعدى، لبهها، منحنىها آغاز مىشود. هشت مرحله در ايجاد يك مدل سهبعدى با اين برنامه بهشرح زير وجود دارد:

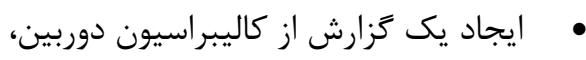

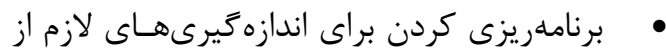
جسم مورد نظر، • عرفتن عكسهاى كافى از تمام وجههاى جسمى

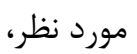
ورود عكس هاى گرفتهشده به برنامه فتومدلر،

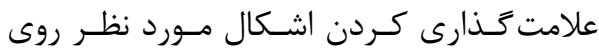

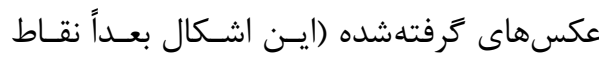
سلبعدى؛ كنترل، كرهاى و ويزه خواهند بود)، بيوند دادن نقاط سهبعدى متناظر در عكسهاى

$$
\text { • مختردازش دادهها، }
$$

استخر اج نقاط سهبعـدى بـراى ورود بـهـ برنامـهـ

$$
\text { مدل سازى. }
$$

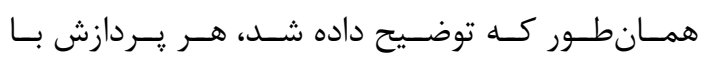
كاليبراسيون دوربين شروع مىشود. در يـروزه مجسـمه دهـ

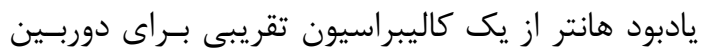

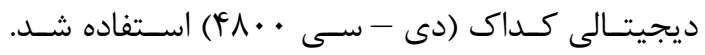

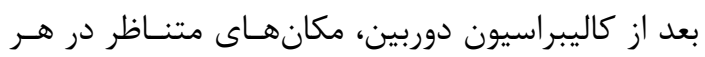
عكس مشخص كرديد. هنكامى كه يك نقطه يا يك خط

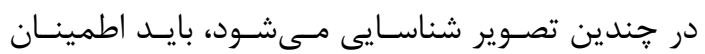

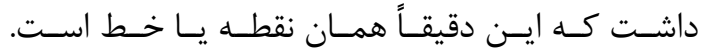

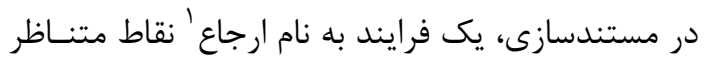

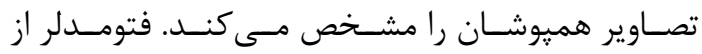

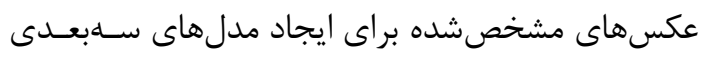
با استفاده از يك فرايند تكرارى تعاملى استفاده مى كند

\footnotetext{
${ }^{1}$ Referencing
} 


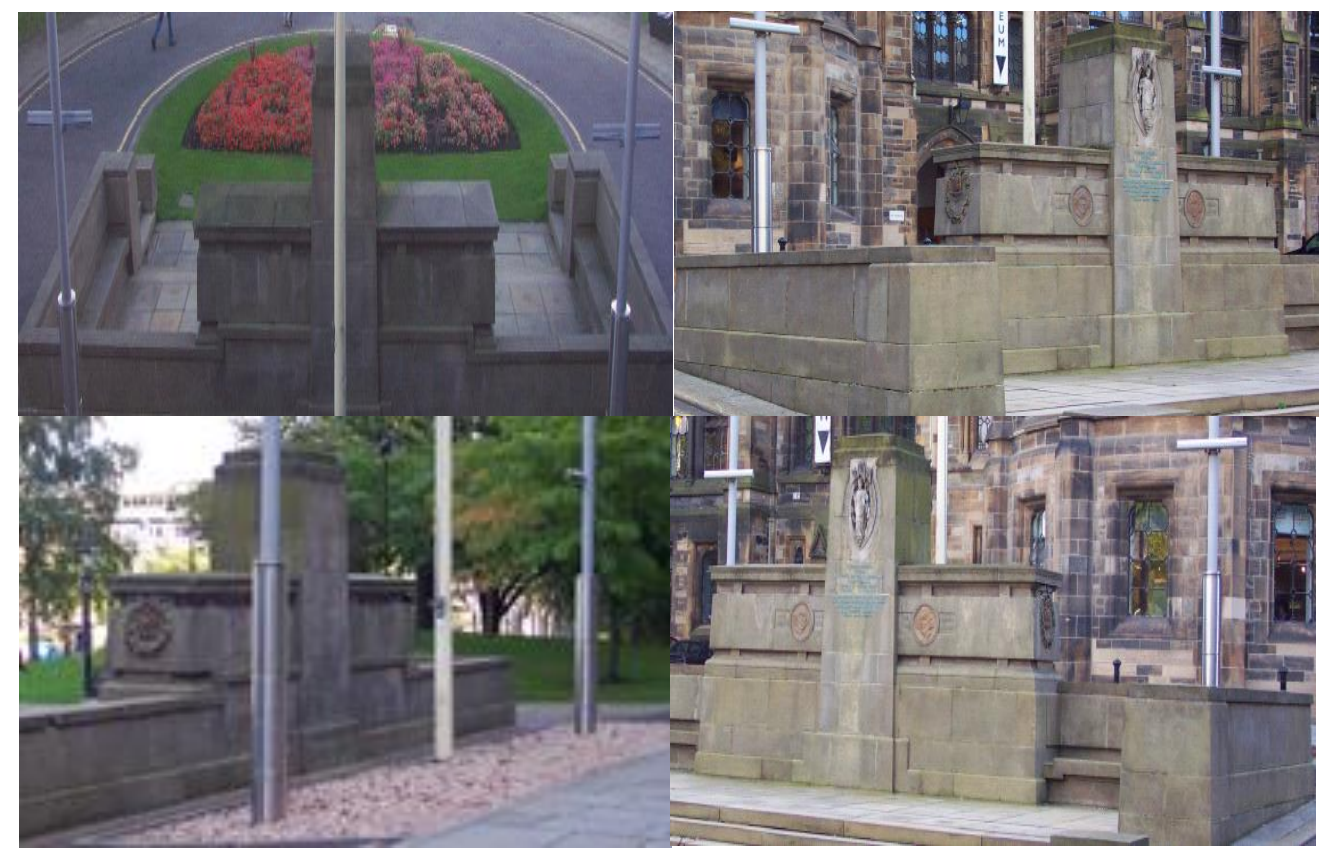

شكل ه: جهار عكس انتخابى براى يردازش يروزه مجسمه يادبود هانتر

ץ-اهميت ترافيك كــامِيوترى در مــدلسـازى

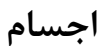

كرافيك كامييوترى براى مدلسازى اجسام، به سه جزء

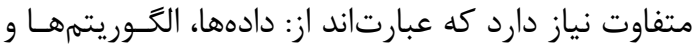

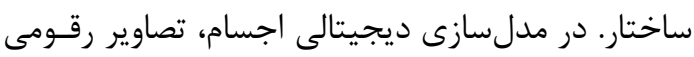

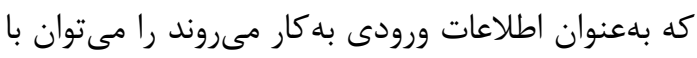

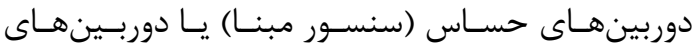

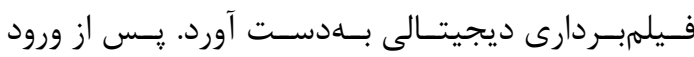

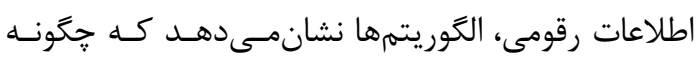
بايد دادهها دستكارى شوند. براى مثال، براى ايجاد يـك مدل سطحى سهبعدى رقومى از عكسهاى اخذشـده از

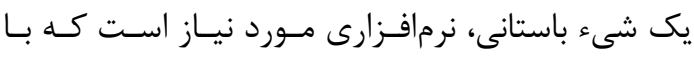

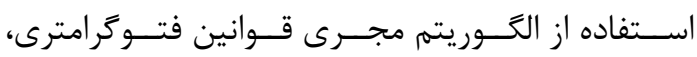

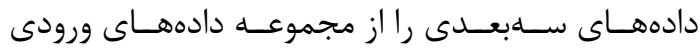

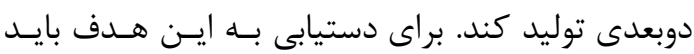

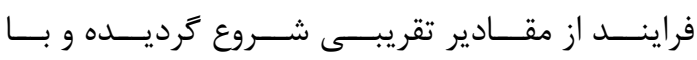
تكرار عمليات بهدقت مورد نظر رسيد.

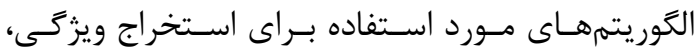

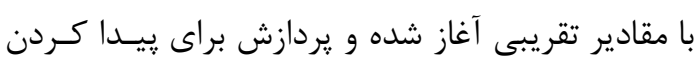

\begin{tabular}{|c|c|c|}
\hline 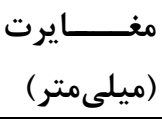 & 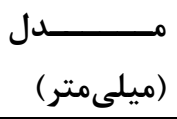 & زمين (ميلى متر ) \\
\hline V & $r v \cdot \Lambda$ & rVID \\
\hline \& & $|F Y|$ & $\| F \mid \Delta$ \\
\hline$\Delta$ & (r) & $\Lambda \mu \Delta$ \\
\hline \& & 941 & $q \pi \Delta$ \\
\hline \& & $\wedge \notin \Delta$ & $\Lambda \Delta 9$ \\
\hline Ir & 0191 & $\Delta \backslash \wedge \Delta$ \\
\hline V & - & خطاى متوسط ريشه \\
\hline rו & - & حداكثر اختلاف \\
\hline
\end{tabular}

r-F- - دقت نتايج حاصله از يروزه يادبود هانتر

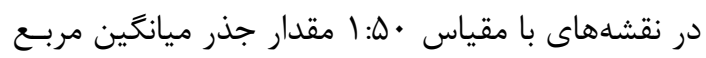

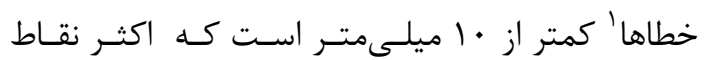

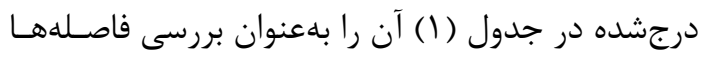
نشان مى دهند.

${ }^{1}$ RMSE 
آسان و سريع به دادهها را فراهم مى كند. در اين يـروزه، ساختار رابطـهاى در نظـر كرفتـهـ شـده اسـت. در ادامـهـ ״يادهسازى برخى از ساختار دادهها را بررسى مى كنيم.

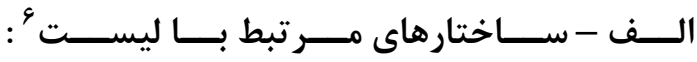

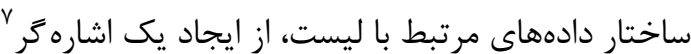
شيئى به اشياء ديكر شكل مى گيــرد. ايسن اشـاره كرهـا،

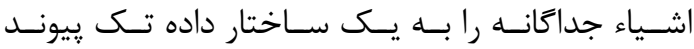

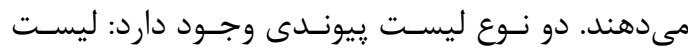

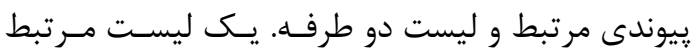

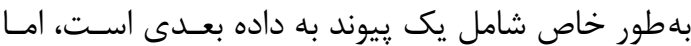

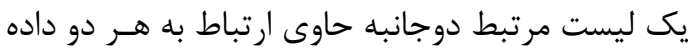
بعدى و قبلى در ليست است [ᄉ].

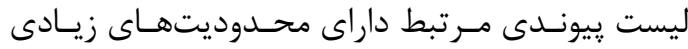

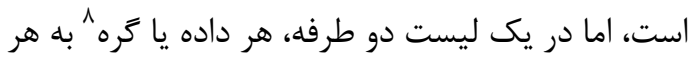

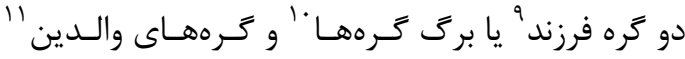
اشاره مى كند. با استفاده از ليستهــاى مـرتبط دوكانـه، جستجوى هر دو به جلو و عقب آسان تر مىشـود. بـراى

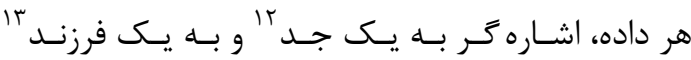

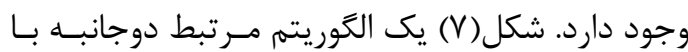
سه داده يا گره را نمايش مى دهد.

\footnotetext{
${ }^{6}$ Linked List Structures

${ }^{7}$ Pointer

${ }^{8}$ Node

${ }^{9}$ Child node

${ }^{10}$ Leaf node

${ }^{11}$ Parent node

${ }^{12}$ Predecessor

${ }^{13}$ Successor
}

موقعيت هر لبه (هر رأس بهعنوان نقـاط سـهبعـدى) بـاـ

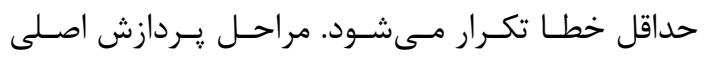
استخراج به شرح زير است:

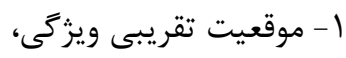

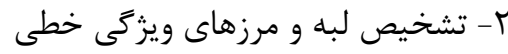

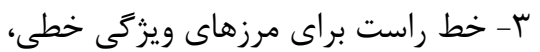

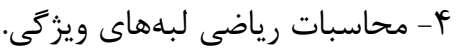

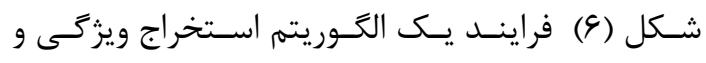

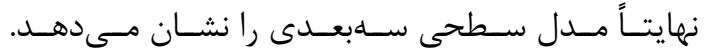
همانطورى كه ملاحظه مسى شـود، ورود دادهــا شـامل

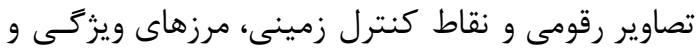

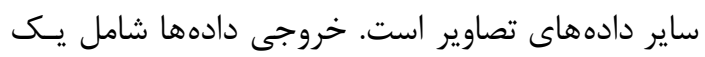

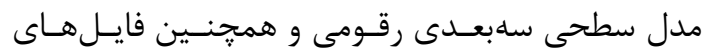

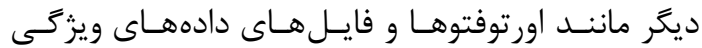

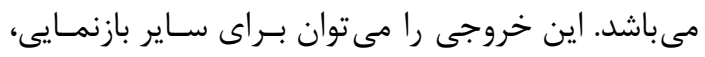

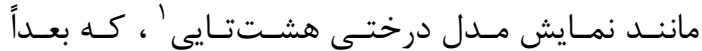
مورد بحث قرار مى گيرد، استفاده نمود.

F - ملاحظات رياضى در ساختار و نمايش اجسـام

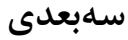
همانطورى كه در بخش بيشين ذكر شد، سومين جـزء

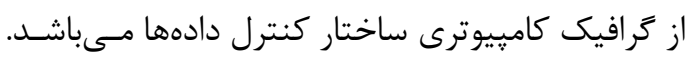

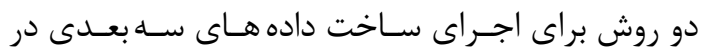
سيستمهاى اطلاعات مكانى وجود دارد كه عبارت اند ازي

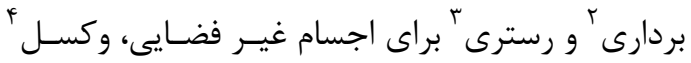

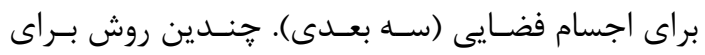

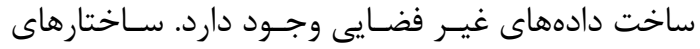

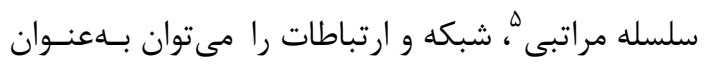

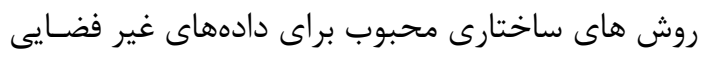

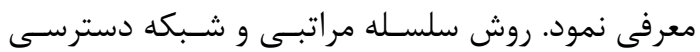

${ }^{1}$ Octal Tree $=$ Octree

${ }^{2}$ Vector

${ }^{3}$ Picxel

${ }^{4}$ Voxel

${ }^{5}$ Hierarchical 

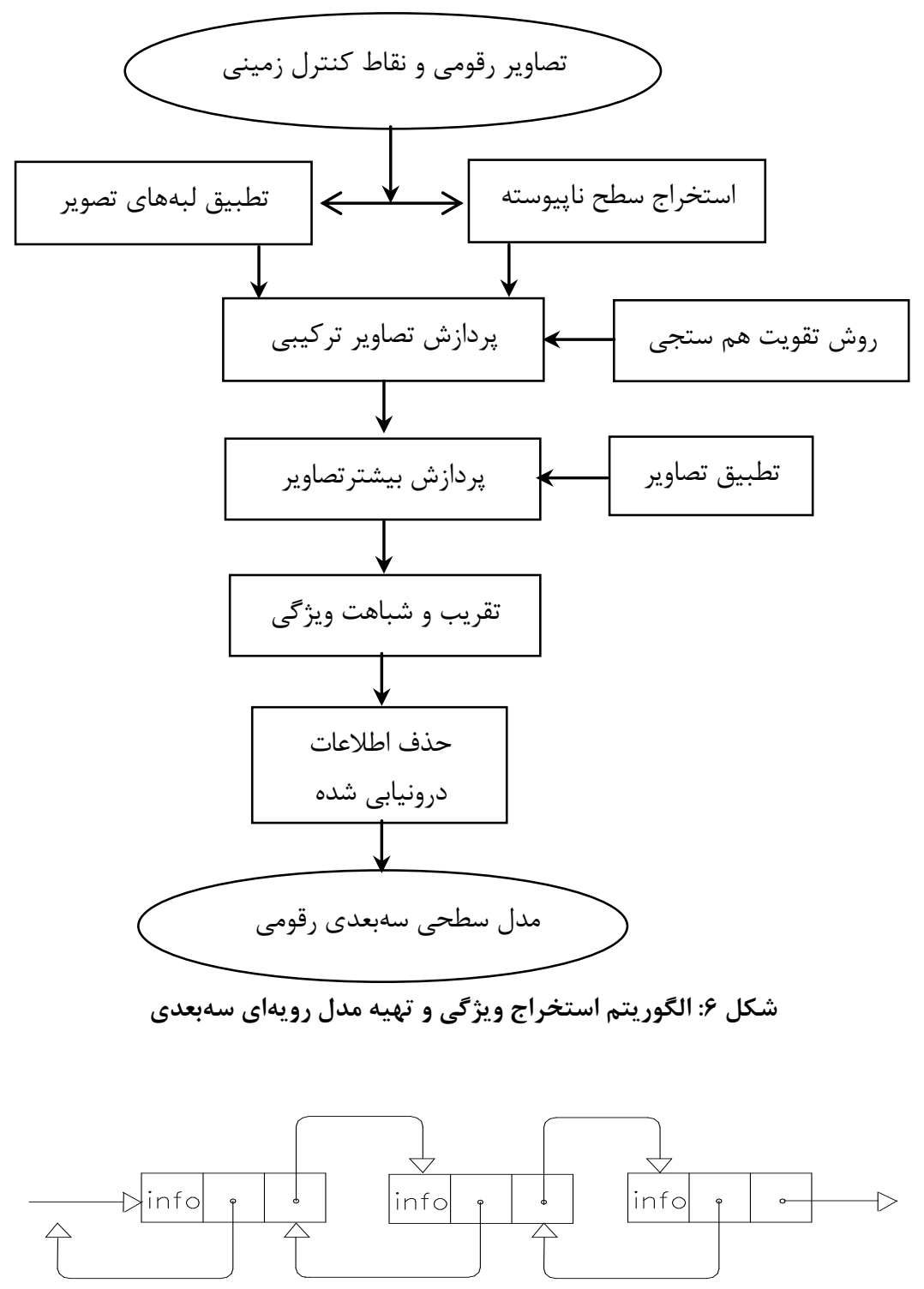

شكل \: يك الخَوريتم مر تبط دوجانبه

توضيح: خانه اول اطلاعات، خانه دوم اشارهخر به گَره عقب، خانه سوم اشارهخر به گَره جلو است.

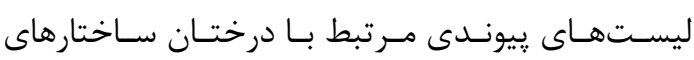

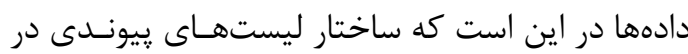

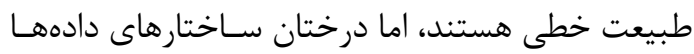

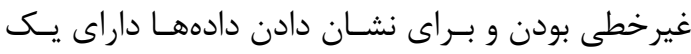

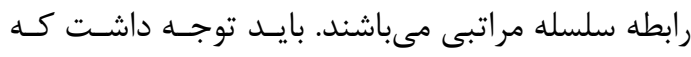

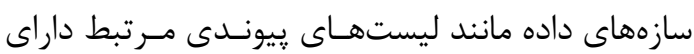
دسترسى ييوسته هستند كه براى رسيدن به يـك كـره هدف لازم است كه از همه گرهه ها عبور كنند. در نتيجه،

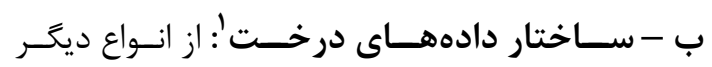

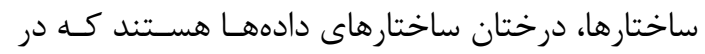

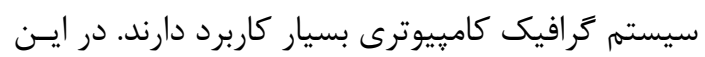

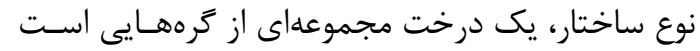

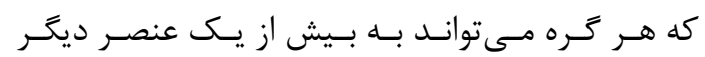

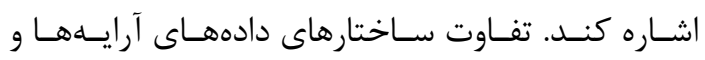

${ }^{1}$ Tree Data Structures 
هندسى استفاده مىشود. شكل (N) يك نمايش ساختار دادههاى درخت دوتايى است.

د- نمــايش سـاختار دادههــاى درخــت ســازنده

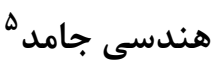
يك شىء سهبعدى كه تركيبى از حجمهاى اوليه (نظير؛

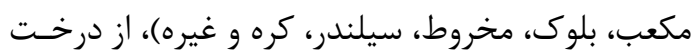

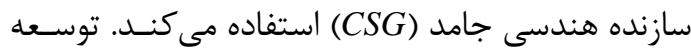

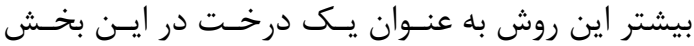
بحث شده است. روش يادشده يك درخت سـاختار داده

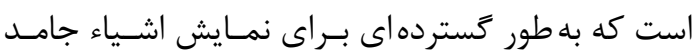

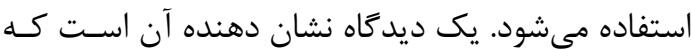

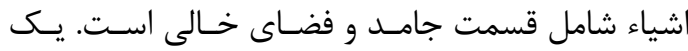

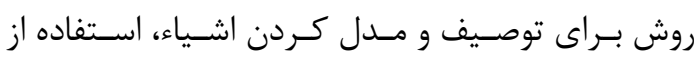
هندسه ساختارى جامد است. اشياء بِيجيده كـه شـكل هندسى ندارند بايد بـهـ شـكل سـاده تـر تجزيـهـ شـــه و

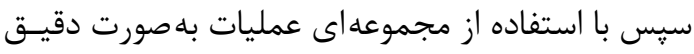

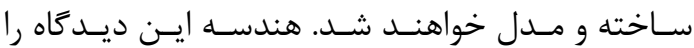
مى توان به عنوان يك درخت هندسه جامد با اشياء اوليه در برك ها (كره هاى نهائى) تعريف كرد و عمليـات را در در

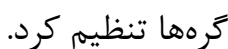

\footnotetext{
${ }^{5}$ CSG Tree Representation
}

براى رسيدن به يك گره كه در انتهاى يك ليست يا در

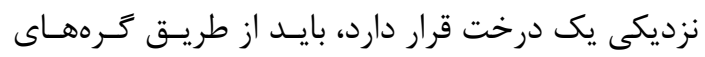

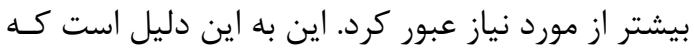

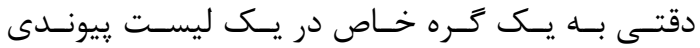
دسترسى پيدا مى كنيم، بهطور متوسط نيـاز اسـت كـهـ

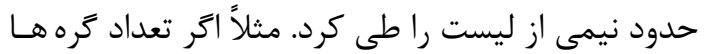

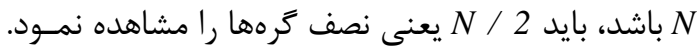

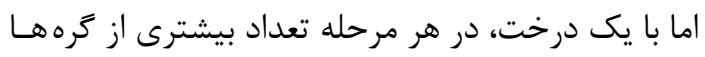

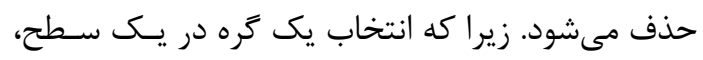

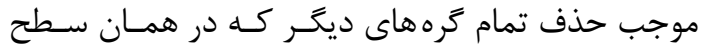

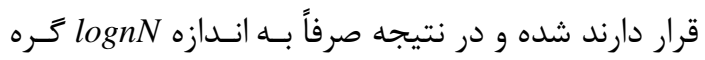
براى رسيدن به يك گره خاص يِيموده مىشود.

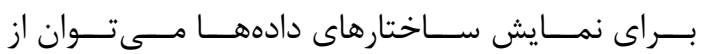

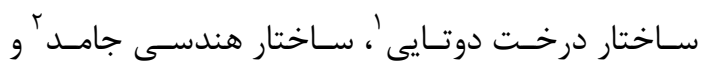

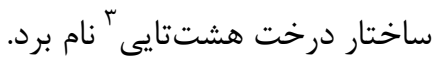

ج - نمايش ساختار دادههاى درخت دوتايى

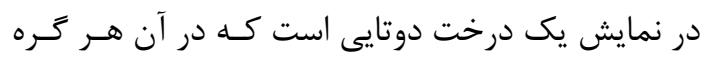

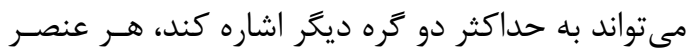

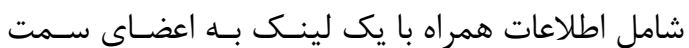
جֶٍ (اول) و يك لينك به سمت راست (دوم) است. هـر

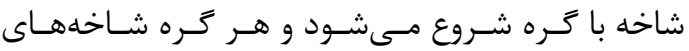
متعددى از آن جدا مى شود. در اين ساختار ريشه اولين

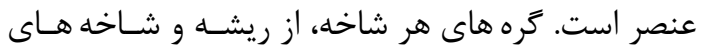

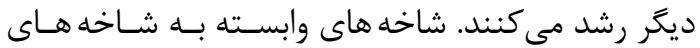

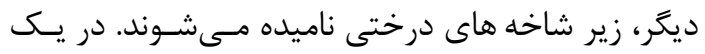

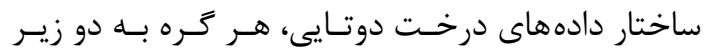

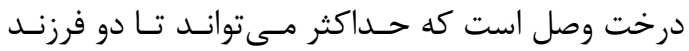

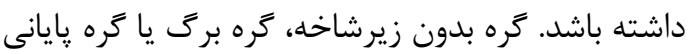

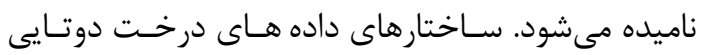

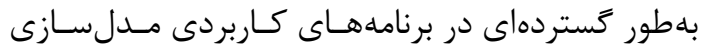

${ }^{1}$ Binary Tree $=$ Bintree

${ }^{2}$ Constractive Solid Geometry $=$ CSG

${ }^{3}$ Octal Tree $=$ Octree

${ }^{4}$ Bintree Representation 


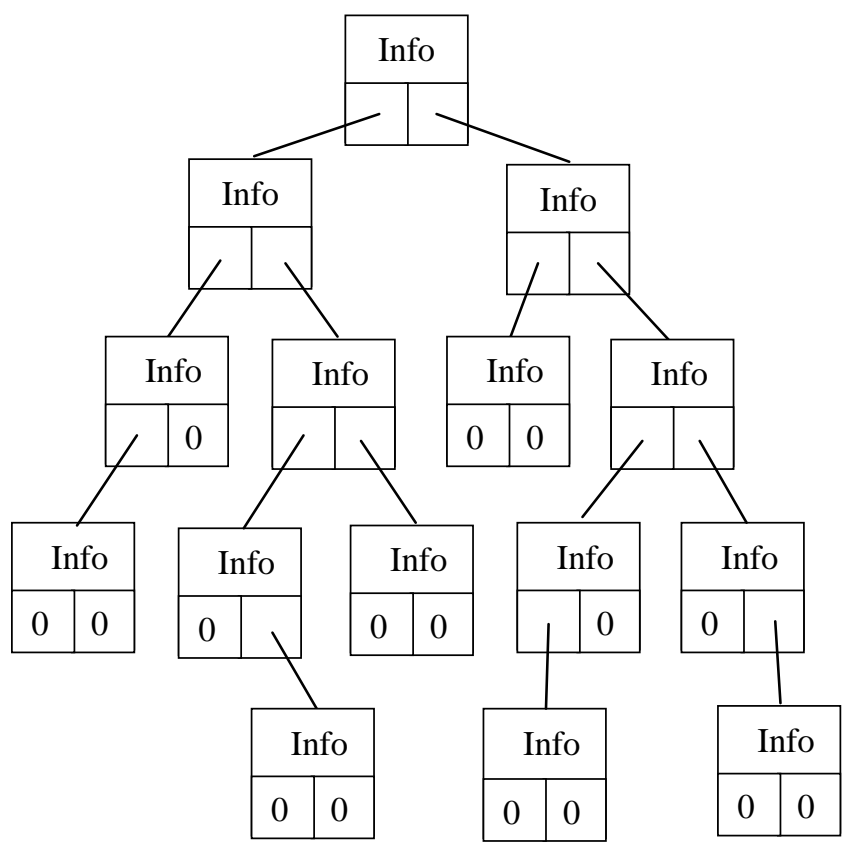

شكل ^: نمايش ساختار دادههاى درخت دوتايى را نشان مىدهد

براى مدل سازى يك شـىء يِيجيـده، سـاختار دادههـاى هموار دارد. اين موضوع با تعريف يك سطح ضـمنى بـهـ

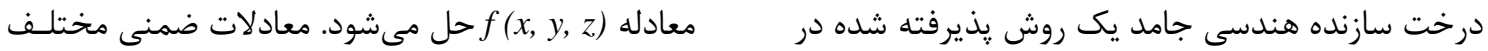

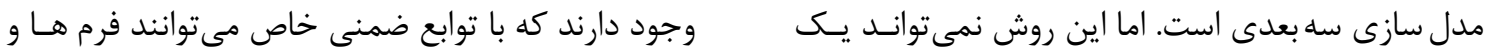

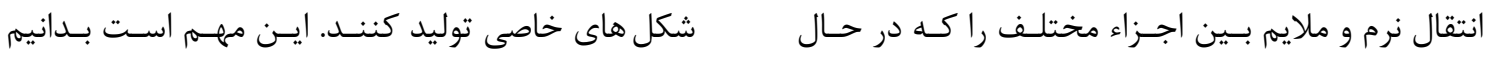

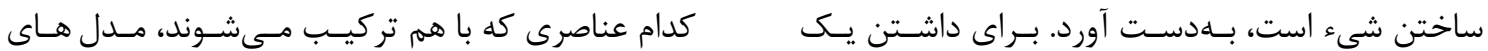

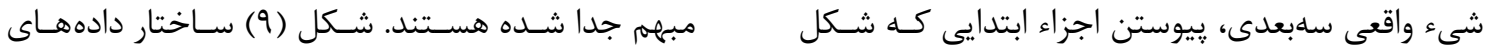

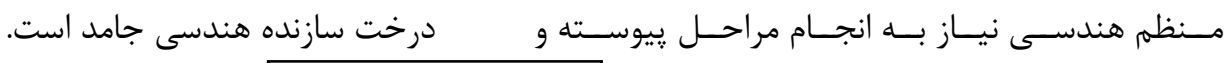

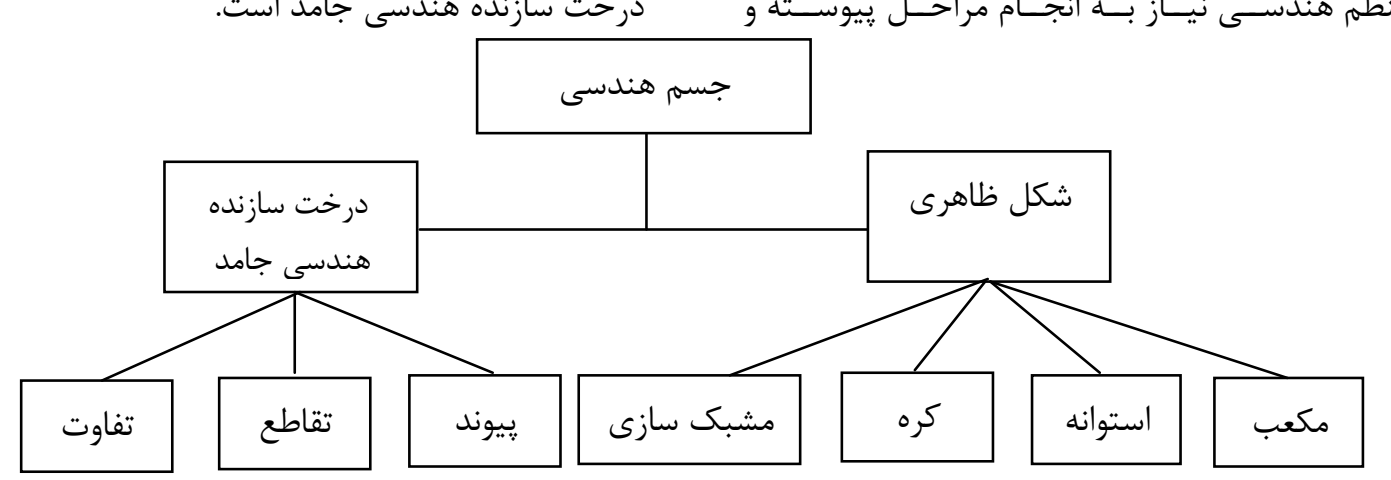

شكل 9: ساختار دادههاى درخت سازنده هندسى جامد

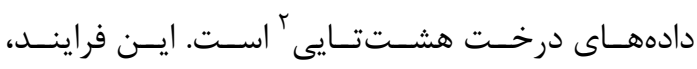
شايعترين طريقه براى فضاى سهبعدى تجزيـه شـده بَّاز

\section{${ }^{2}$ Octree}

${ }^{3}$ Decomposition
هـ - نمايش ساختار دادههاى درخت هشت تايى' يكى از روش هاى متداول براى مدل كردن دنياى واقعى و اجسامى كه فضا را اشغال مى كنـــد، نمـايش سـاختار

${ }^{1}$ Octree Representation 
F-F - بر رسى الكَوريتم هاى رياضى در مدل سازى

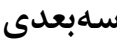

دستخاه مختصات دكـارتى سـهبعـدى بـهـــــوان محـل مناسب براى نمايش نقاط سهبعدى ييشنهاد شده اسـت تا در فتو گرامترى موقعيت نقاط در فضا مشخص كردد.

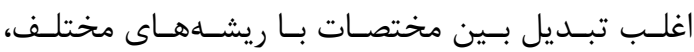

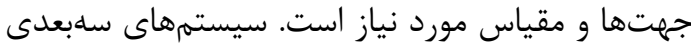

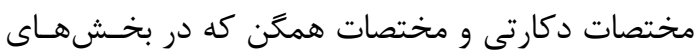

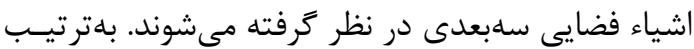

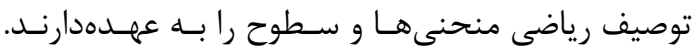
براى اين يروزه، و تجسم سلبعدى و استخراج يك شكل

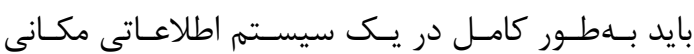

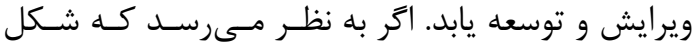

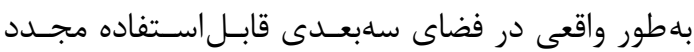

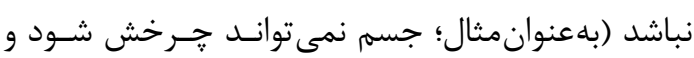
نقاط سهبعدى اي را نمى تـوان اسـتخراج كـرد)، معلـوم

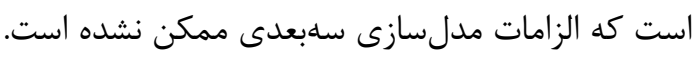

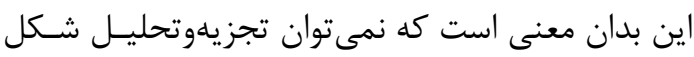

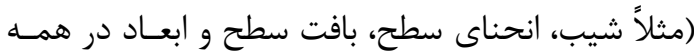

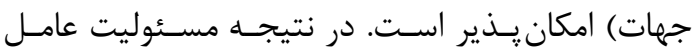

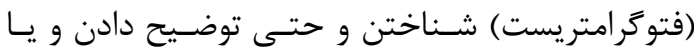

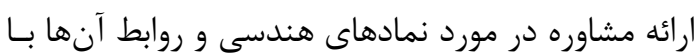

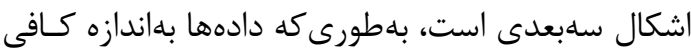

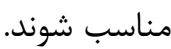

\section{F-F- F- معادلات رياضى در مدلسازى اجسام}

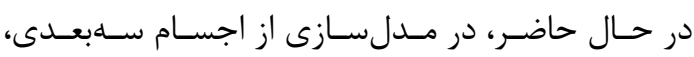

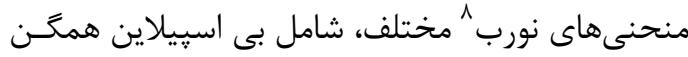

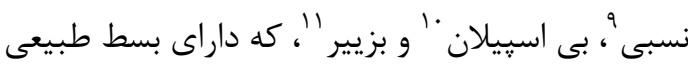
براى سطوح بوده و محبوب ترين منحنى هستند، به كار

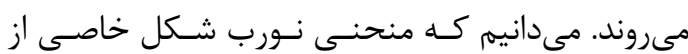

\section{${ }^{8}$ NURBS}

${ }^{9}$ Uniform Rational B-Spline

${ }^{10} \mathrm{~B}$-Spline

${ }^{11}$ Bézier
سلسله مراتبى' يك شىء است كه يك مكعب محـدود

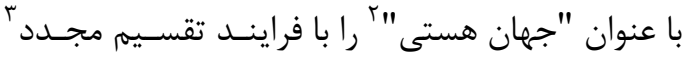
كد مى كند درست مىشود. اين"جهان هستى" به بـ تدريج

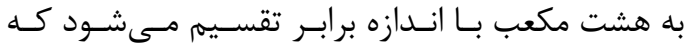

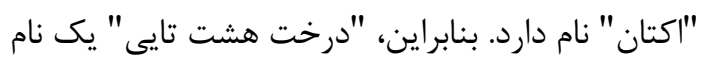
مناسب براى نمايندكَى اين درخت است.

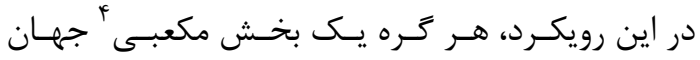

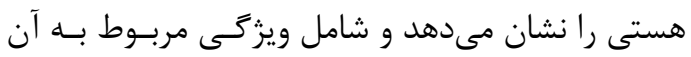

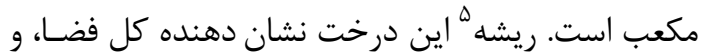

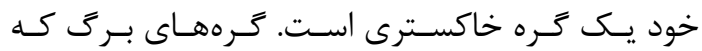
كرههاى پايانى هستند، شامل مكعبهاى واحد با همان

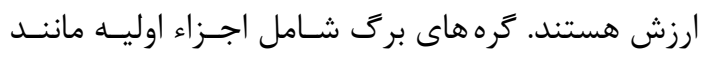

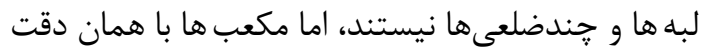

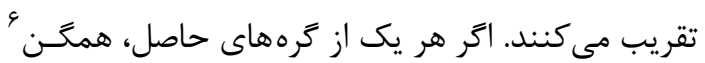

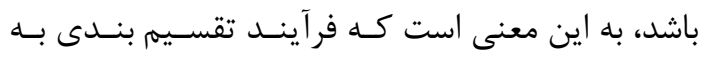

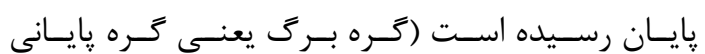

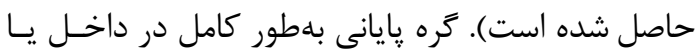

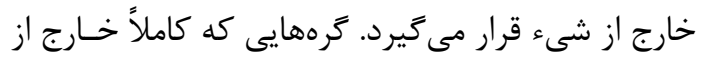

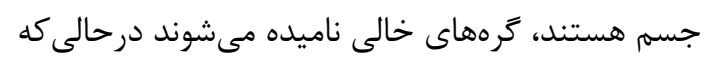

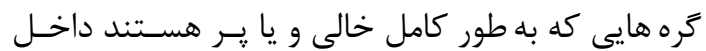

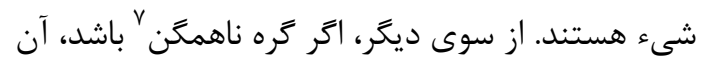

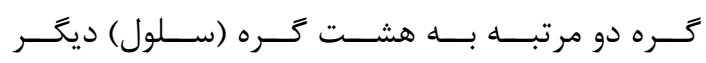
تقسيم مىشود كه همخَن هستند. كَرهاى غيـر پايـانى (كره هاى خاكسترى) كه ناهمكن يا نيمه كامل هستئند

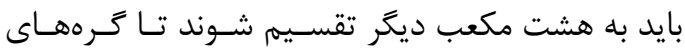

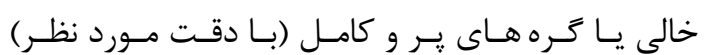
به دست آمده و عمل سلسله مراتبى يايـانيافتـه و كليـهـ

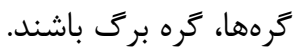

\footnotetext{
${ }^{1}$ Hierarchical

${ }^{2}$ Universe

${ }^{3}$ Recursive method

${ }^{4}$ Cubical

${ }^{5}$ Root

${ }^{6}$ Homogenous

${ }^{7}$ Heterogeneous
} 


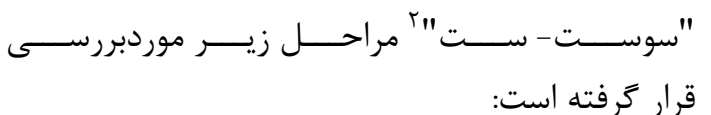

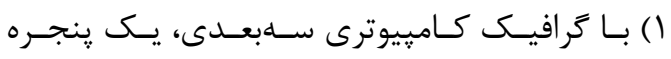
ايجاد كرده است،

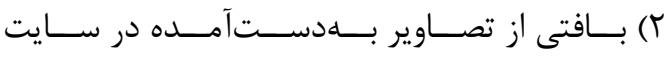
حاصلشده است،

r) رديابى و رندر كردن تصاوير انجامشده است،

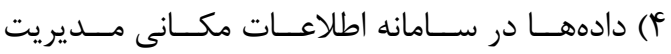

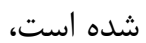

ه) نقاط دادهده ابتدا مشتق شده و سيس در محيط

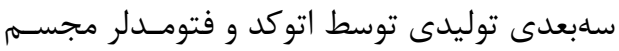
كرديده و موردبررسى قرار كرفته است، توسط استو ؟) يك مدل سطحى بافتى از محسيط در يـك ينجــره براى دادهها تعبيهشده است،

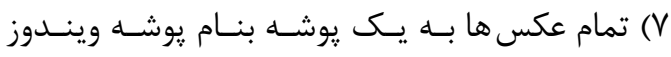

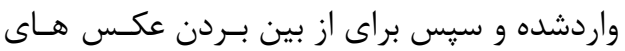
ضعيف موردبر رسى قرار ترفتند و همجنين بـراى براى

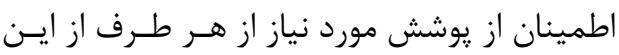
شىء موردبر رسى قرار خرفت.

\section{ه- تشكيل مدل سطحى سهبعدى رقومى}

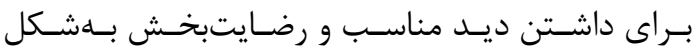
كرافيكى رقومى (رسترى) از يك شىء كه آثار باسـتانى

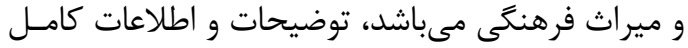

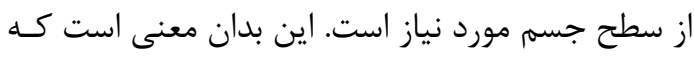
تفسير بيشترى از اجزاء جسم بايد به اطلاعات قبلى كه

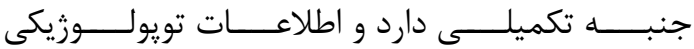

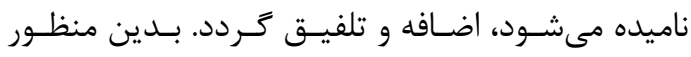

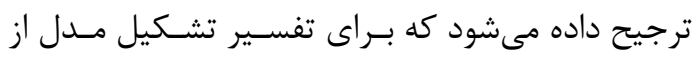
تكنيك (تين) كه بعداً توضيح داده خواهد شد، اسـتفاده

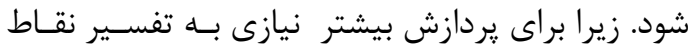

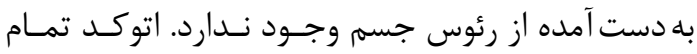
مختصات رئوسى كه در حال حاضر ذخيرهشده را از يك

${ }^{2}$ Socet Set
منحنىهاى بـى اسييلاين است و ازجملـه عمـومىتـرين

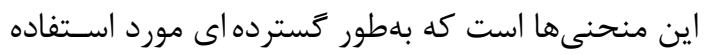

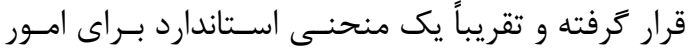
صنعتى به شمار مىرود. از نظر رياضى، "غيريكنواخت"

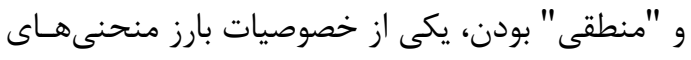

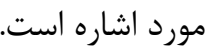
برخـى از تكنيــهــاى درونيـابى، سـطح ارزش نقــاط

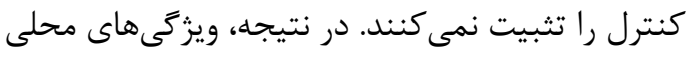

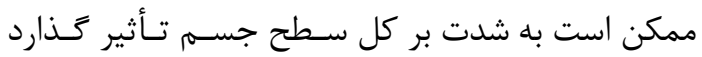

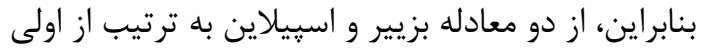
براى نقاط كنترل و تعيين شكل سطح مــدل مسىتـوان

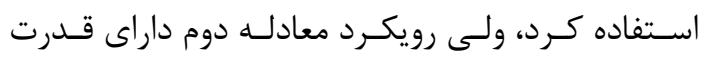
كنترل شكل محلى است. مزيت استفاده از رويكـرد بسى

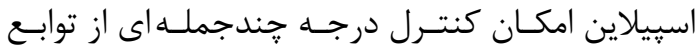

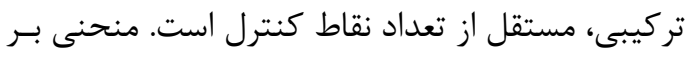

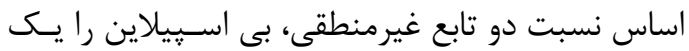

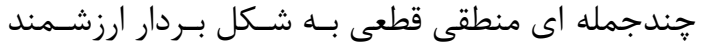

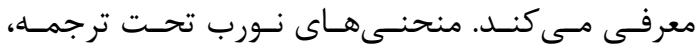

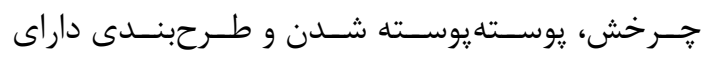
جشهماندازى غيرقابل تغيير است. F-F- F- تشكيل لايهها در نرمافزار اتوكد سيستم كد قادر به ارائه دادها براى لايههاى مختلـف و

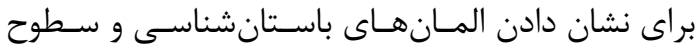

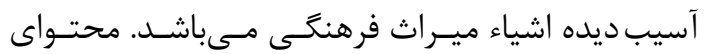

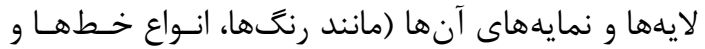

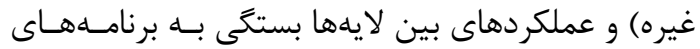
ييشنهادى داشته و سطوح مختلف شىء براى تحقيقات بيشتر در سيستم (A / AIS) بايخانى مىشود

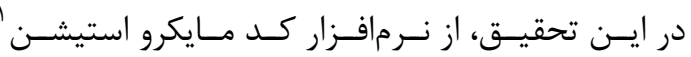
استفاده كرديد و در نتيجه مدل دقيق سطحى سلبعدى إنسار بخشى از ساختمان ساخته شد و با استفاده از مختصات سهبعدى حاصل از فتوكرامترى رقومى با برنامهاى بنـام

\footnotetext{
${ }^{1}$ Intergarph MicroStation (Bentley)
} 


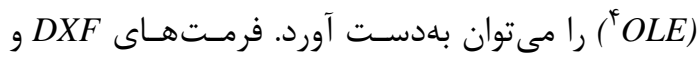

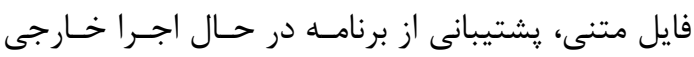

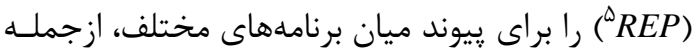

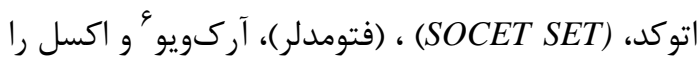

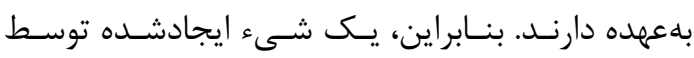
اتوكد مى تواند بهعنوان يك شـى

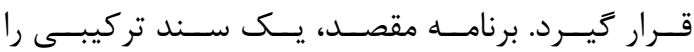

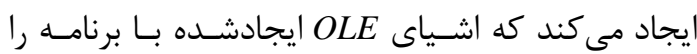

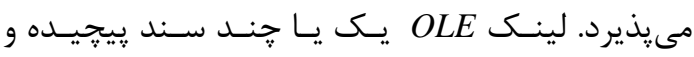

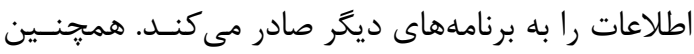

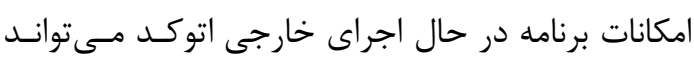

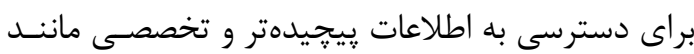

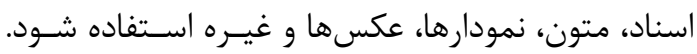

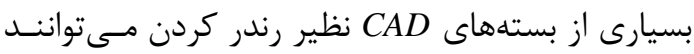

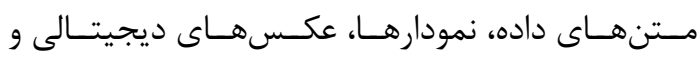

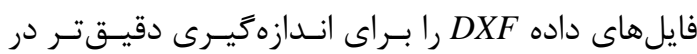
برنامههاى (A / AIS) وارد كنند.

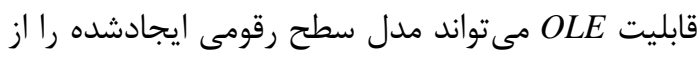

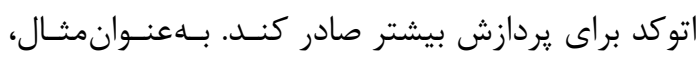

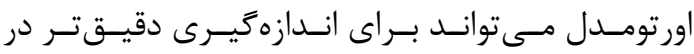
برنامههاى (سوست- ست) و فتومدلر استفاده شود. بايد

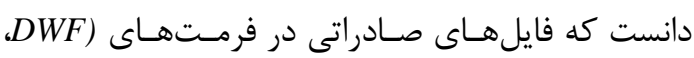

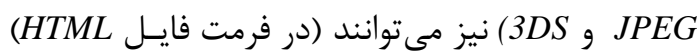

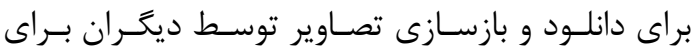
اهداف آينده به وب صادر شوند.

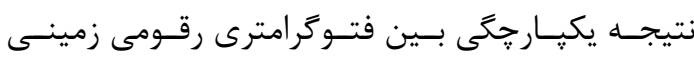

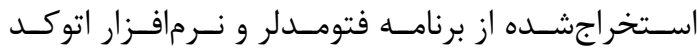
بلهورت مدل سيم قاب رشتهاى لاست. در اين توسعه،

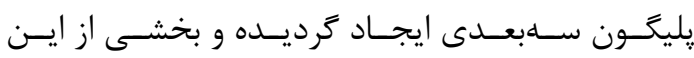
(به عنوان نمونه) در جدول (T) نشـان داده شـــه اسـت.

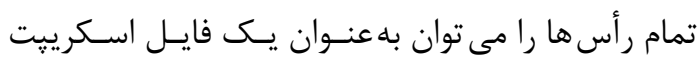

\footnotetext{
${ }^{4}$ Object Linking and Embedding

${ }^{5}$ Run external program

${ }^{6}$ ArcView

${ }^{7}$ Wire-frame Model
}

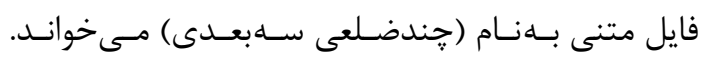

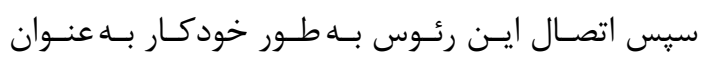

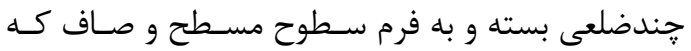

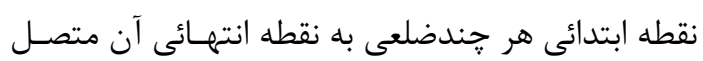

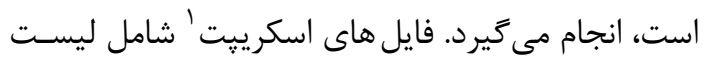
تمام صفحات مسطح كه سطح بيرونى جسم را تشـكيل

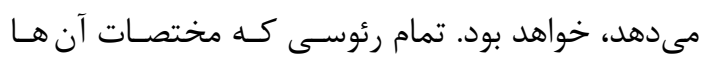
بهعنوان نقاط سهبعدى ذخيرهشدهاند بيانكر يك ســ دهح

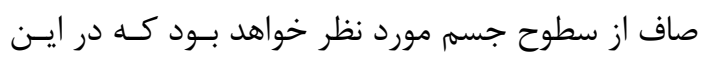

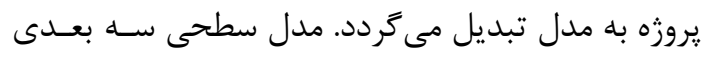

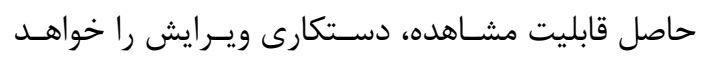

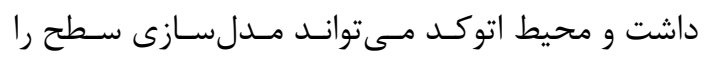

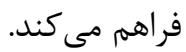

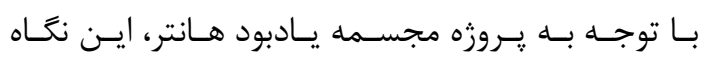

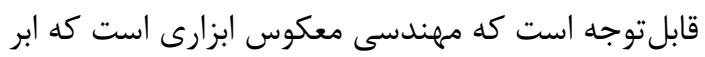

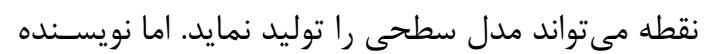

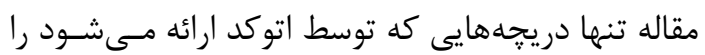

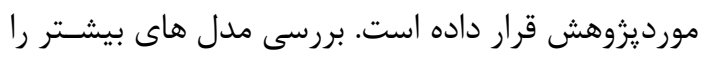

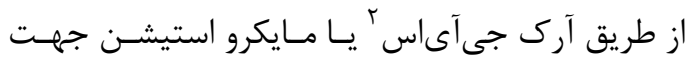

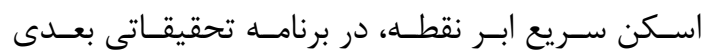

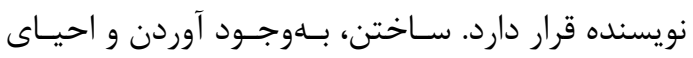

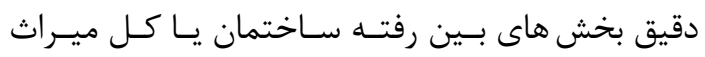

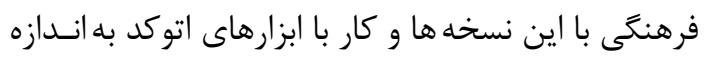

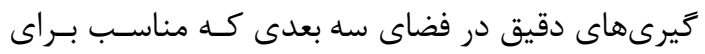

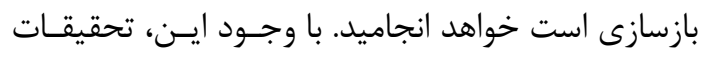

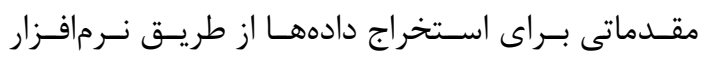
فتومدلر در اين مقاله صورت گرفته است.

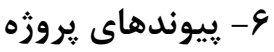
فرمت هاى واسط مانند فايل هاى دىاكساف (

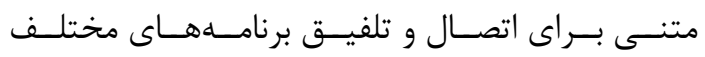
استفاده مىشوند. در نتيجه؛ أتصاء

\footnotetext{
${ }^{1} 3$ dpoly.scr

${ }^{2}$ ArcGIS

${ }^{3}$ Data eXchange Format
} 


$$
\begin{aligned}
& \text { مدل قاب رشتهاى > }
\end{aligned}
$$

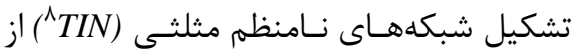

$$
\begin{aligned}
& \text { سطوح }
\end{aligned}
$$

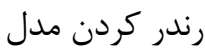

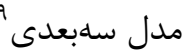

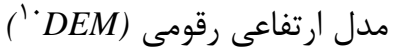

$$
\begin{aligned}
& \text { I-V }
\end{aligned}
$$

براى مجسم كردن يك اثر باستانى و معمارى، توصـيف

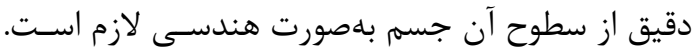

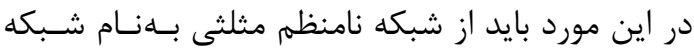

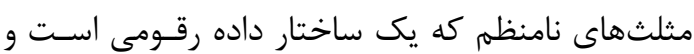
بهاختصار TIN ناميده شده و در سيستم اطلاعات مكانى براى نمايش يك سطح از آن اسـتفاده مسى خـردد، بهـره جست. دليل ترجيح دادن استفاده از TIN براى مجسمه يادبود هانتر اين است كه براى يردازش بيشـتر سـطوح

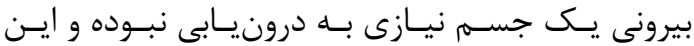

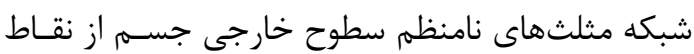

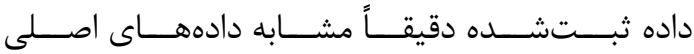
ايجاد مىشود. شكل (• () مدل تشـكيلشـده از شـبكه مثلثهاى نامنظه بالاى قسمت ميانى از مجسمه يادبود

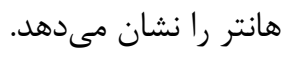

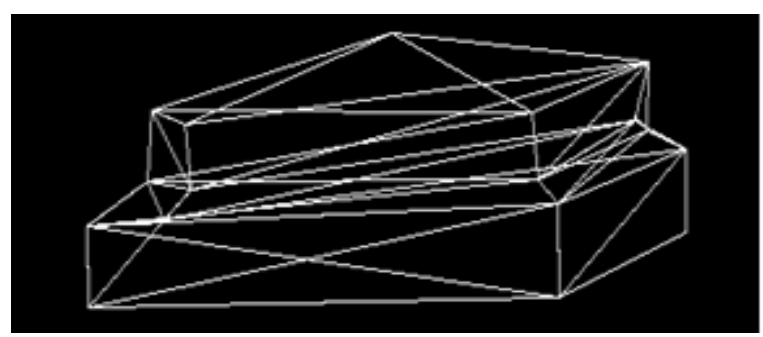

شكل • ا : مدل TIN بالاى قسمت ميانى از مجسمه يادبود هانتر

\footnotetext{
${ }^{7}$ Wire-frame Model

${ }^{8}$ Triangulated irregular network

9 3D Model

${ }^{10}$ Digital Elevation Model
}

$$
\begin{aligned}
& \text { موردبررسى قرار داد كه در اتوكد براى يــردازش بيشـتر } \\
& \text { در دسترس است. اين فايل همجنـين مى تواند بـهـعــــان } \\
& \text { مستندسازى آثار باستانى ذخيره شود. }
\end{aligned}
$$

V - استخراج دادهها و تجسم مدلهاى رقومى دادههاى اسـتخر اجشـده از (AIS / A از نـوع دادهــاى

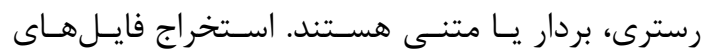

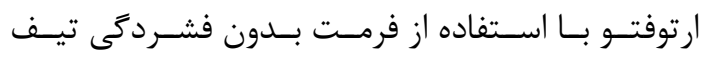

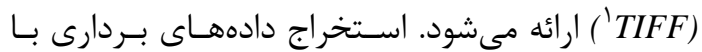
فرمت DXF تعداد زيادى خروجى با فايلهـاى بـردارى در دسترس قرار مى دهد. در نتيجه، يك فايـل متنسى از

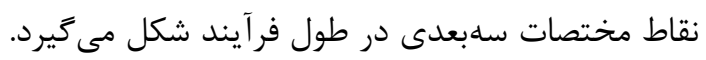
آمادهسازى يك فايل اسـكرييت (3dpoly.scr) از نقــاط سهبعدى ذخيرهشده كه به اتوكد واردشده است، تجسم إنس

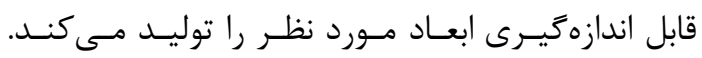

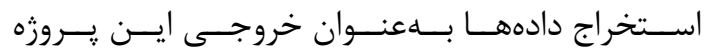
نشان مىدهد كه هر با بسته رقومى (تصـاوير رقومى)

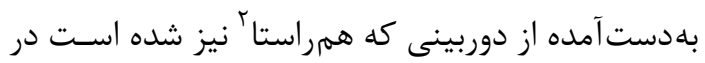

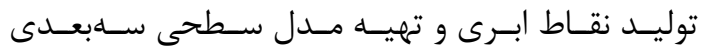

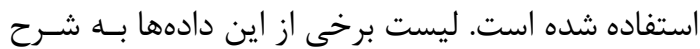

$$
\begin{aligned}
& \text { زير است: } \\
& \text { نقاط سهبعدى" }
\end{aligned}
$$

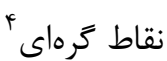

$$
\begin{aligned}
& \text { سطوح سهبعدى و مسطحهّ } \\
& \text { • • • } \\
& \text { فايلهاى متنى و DXF } \\
& \text { توليد تراكم ابر نقاط }
\end{aligned}
$$

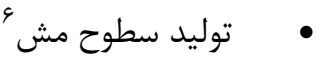

$$
\begin{aligned}
& \text { • • • • • } \\
& \text { تهيه ارتو موزاييك ترن }
\end{aligned}
$$

${ }^{1}$ Tagged Image File Format

${ }^{2}$ Aligned

${ }^{3}$ Vertices

${ }^{4}$ Tie Points

${ }^{5}$ Facets

${ }^{6}$ Mesh Faces 
جدول r : فايل كزارششده از يليگون سهبعدى براى مدلسازى از سطوح مجسمه يادبود هانتر

Polyline Layer:"0"

Space: Model space

Handle $=437$

Closed space

First 3 points did not define a plane. No area calculated Vertex Layer: "0"

Space: Model space

Handle $=438$

Space at point, $\mathrm{X}=10.18 \mathrm{Y}=12.08 \mathrm{Z}=-459.62$

VERTEX Layer: "0"

Space: Model space

Handle $=439$

Space at point, $\mathrm{X}=10.18 \mathrm{Y}=12.08 \mathrm{Z}=-459.62$

Vertex Layer: "0"

Space: Model space

Press Entre to continue:

Handle $=43 \mathrm{a}$

Space at point, $\mathrm{X}=10.18 \mathrm{Y}=12.08 \mathrm{Z}=-459.62$

End Sequence Layer: "0"

Space: Model space

Handle $=43 \mathrm{~b}$

Polyline Layer: "Default"

Space: Model space

Colour: 7 (white) Line type: "Bylayer"

Handle $=2 \mathrm{a}$

Poly face mesh

Vertex Layer: " Default "

Space: Model space

Color: 7 (white) Line type: " Bylayer "

Handle $=2 \mathrm{a} 3$

Poly face vertex at point, $x=31.56 \quad y=-25.88 \quad z=-391.73$ 
عمليات بين لايهها بسـته بــه برنامـهـهـاى بيشــنهادى،

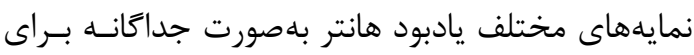

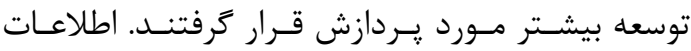

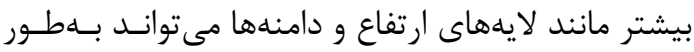
مستقيم از مدل سطح توليد شده استخراج و بــــــــــــان

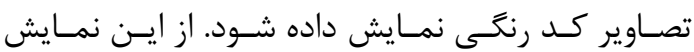

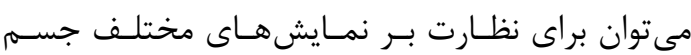

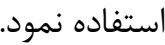

\section{9- توليد و استخراج مدلهاى رقومى}

نقشههاى بافتى در نمايش (جهره) انسـان بسـيار مهـم

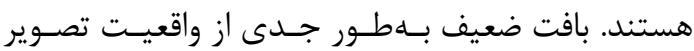
منحرف مىشود. يك روش كه اخيرا" توسعهيافتسه و در

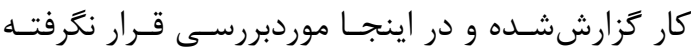
است، شامل بافت تصوير ليزرى است. ليزر اسـكنر قـادر

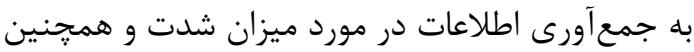

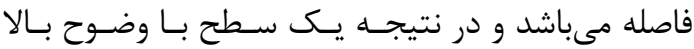
برداشت مىنمايد. تصاوير اسكن شده با استفاده از يـــ اسكنر ليزرى با وضوح بسيار بالا مىتوانند با اسـتفاده از

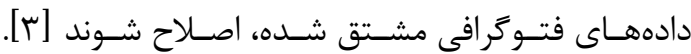

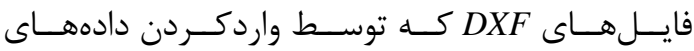

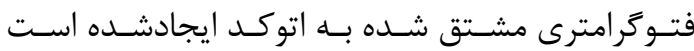
مىتوانند براى توليد مدل قاب سهبعدى استفاده شـوند

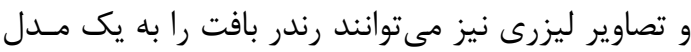
سلبعدى رقومى اضافه كنند. دادههايى كه مىتوانند از فتومدلر صادر شوند، دادهــاى

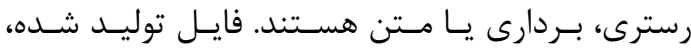

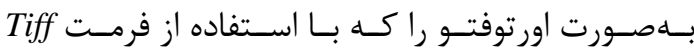

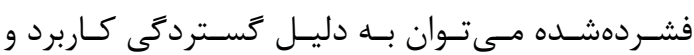

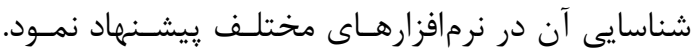

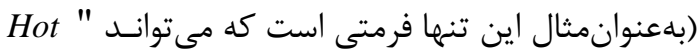

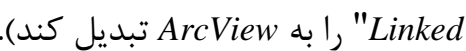

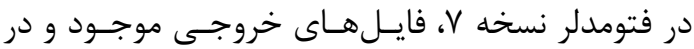

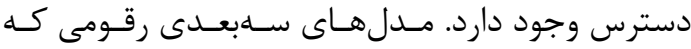

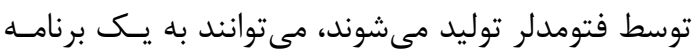

- r-V

كرافيك كامبيوترى، تردازش تصاويرى از اشياء واقعى يا مدرد

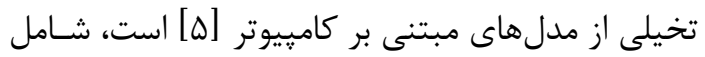

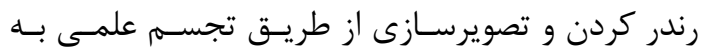

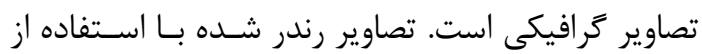

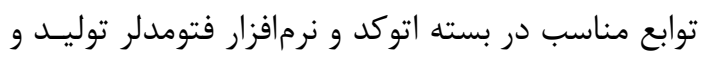

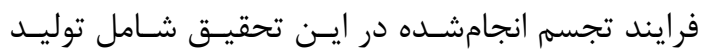
نمايههاى مجسمه يادبود هانتر بود. سختافزار كرافيكى دئى

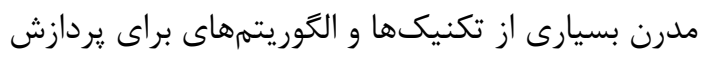

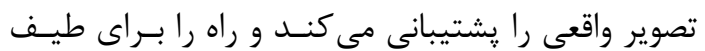
وسيعى از برنامهها باز مى كند.

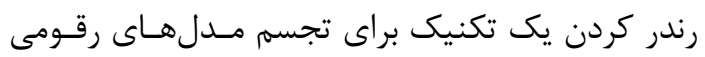
است. براى بهبود تصور مدل سطح مى توان جهت نور راك راك تغيير داد. شكل (1 ) (1) رندر قسمت بالاى سـتون ميسانى مجسمه يادبود هانتر را نشان مى دهد. فتومدلر همجنين

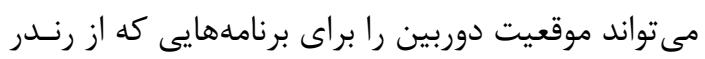

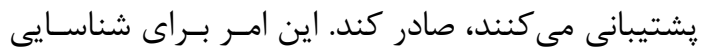
جـايى اسـت كـه دوربــين قـرار دارد. بنـابراين، كـاربر

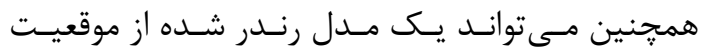

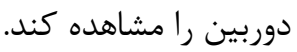

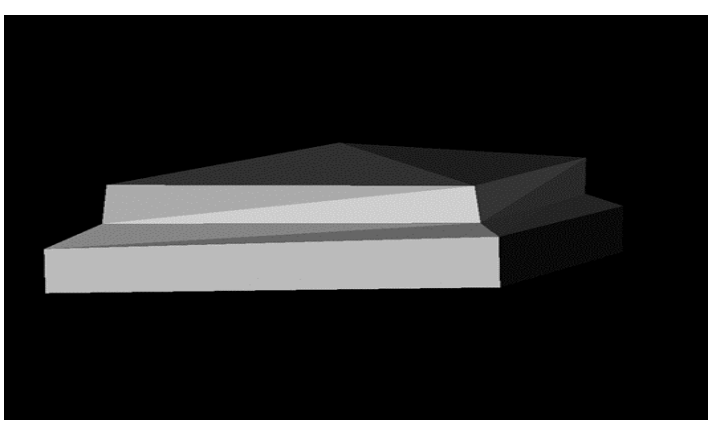

شكل / / :مايش مدل رقومى بالاى ستون ميانى مجسمه

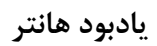

1- استخراج اطلاعات رقومى

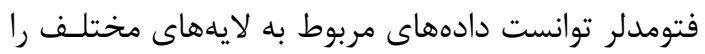

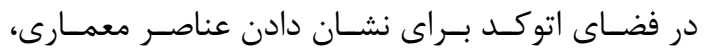

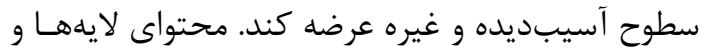

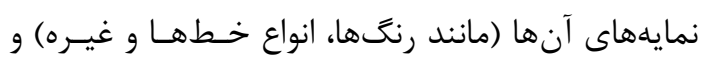


1 - 1 - 1حث و نتيجهَيرى. تكنيكهاى فتوكرامترى مزاياى بسـيارى بـراى ثبـت و

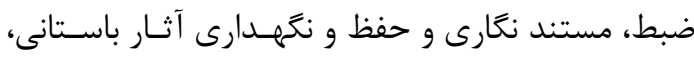

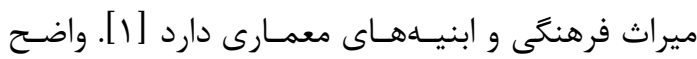

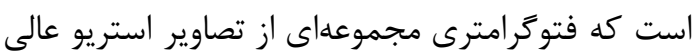

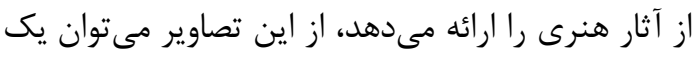

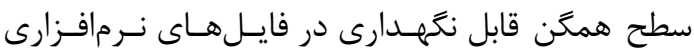

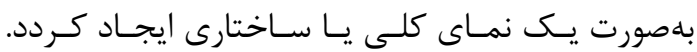
اين سطح اغلب مستقل از سطح جزئيات اسـت. كـاربرد اين گونه تكنيكها، مزاياى ديكرى نيز دارد كه عبارتاند

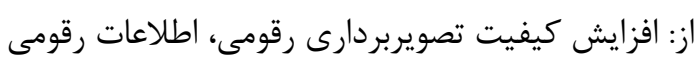

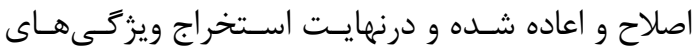

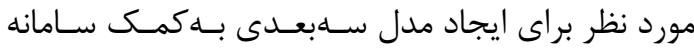

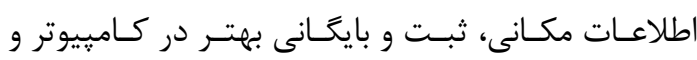

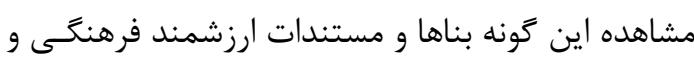

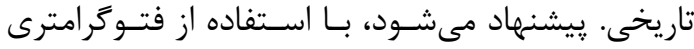
رقومى بهسرعت و يـيش از فعاليـتهـاى ديخـر سـايت عمليات مانند ايجاد داربست، مدل سهبعدى دقيق توليد

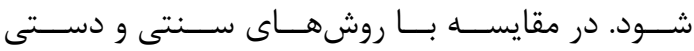

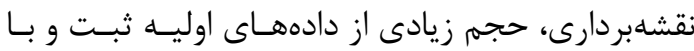

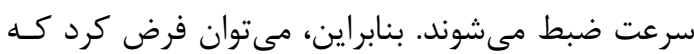

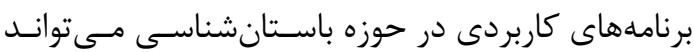

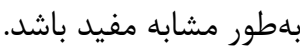

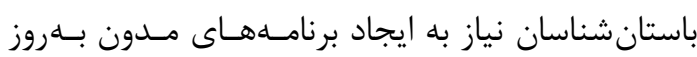

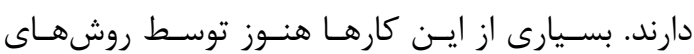

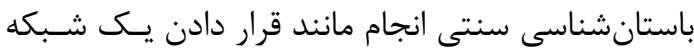

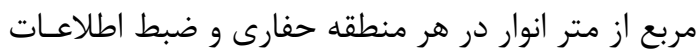

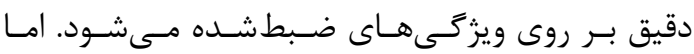

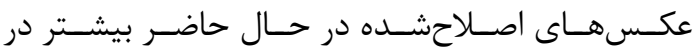
زمينههاى باستانشناسى مورد استفاده قرار مى گيرند، و واصنا

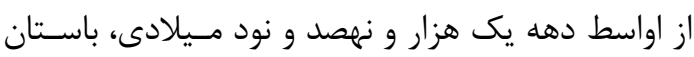

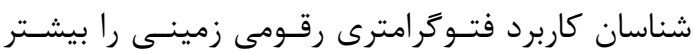

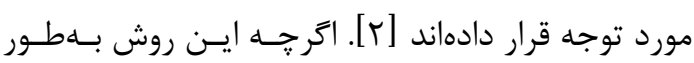

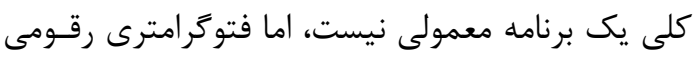

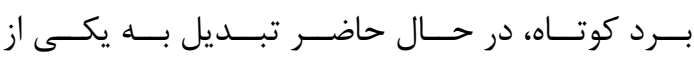

ديخر صادر شوند. براى مثال يك برنامـهـ (CAD-PMP)،

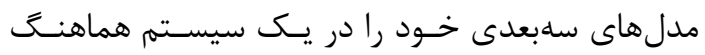
توليد مى كند. هنخامى كه يك مدل سهبعدى صادر شود،

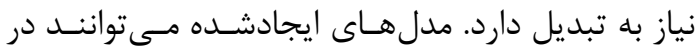

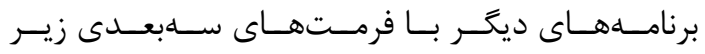

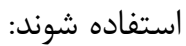
و(IGES _ XVRML_OBJ_ $\left.3 D S_{-} D X F\right) \bullet$

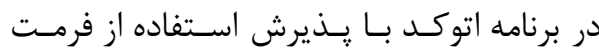

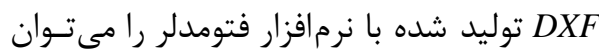
با استفاده از ابزارهاى موجود، دستكارى و رنسدر

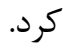

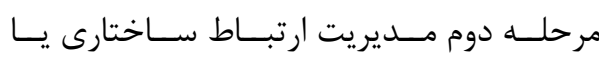
تويولوزيكى بين وازگًان است. ايـن روش شـامل

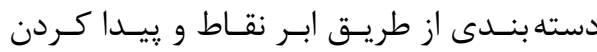

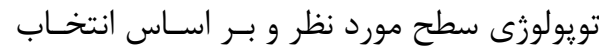

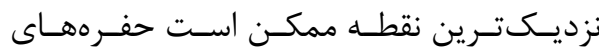
سطحى يا و كسلهاى سطح جسم را ييدا كنــد. فرض بر اين است كه عكسـ بــردارى يِيشـرفته، ازجمله كاليبراسيون دوربـين، مسىتوانـد نتـايج اين تحقيق را بهبود بخشد.

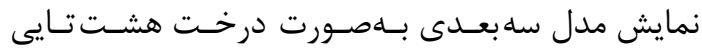

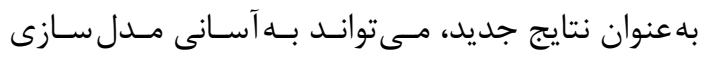

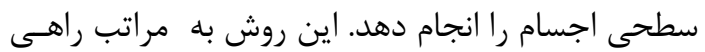

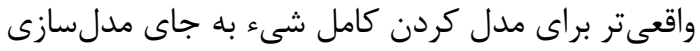

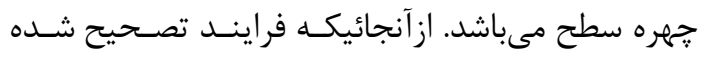
به صورت يِيكسل به بِيكسل در مقياس اورتوفتـو انجـام مىشود، يك مدل سطحى رقومى بــا وضـوح بـالا مـورد

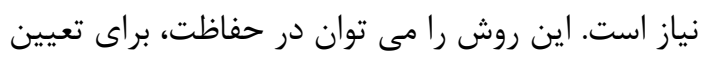

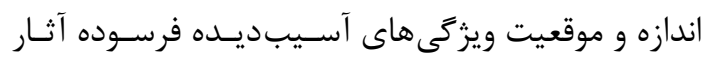
باستانى بهكار برد. ايـن تحقيـق، جزئيـات سـه بعـدى و و تصاوير اورتوفتوئى از مجسمه يادبود هـانتر ارائسه كـرده

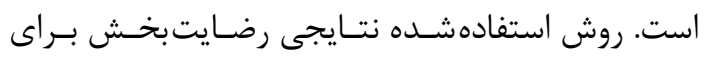

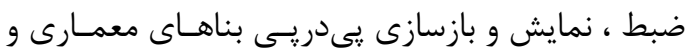
تحليل ديجيتالى آنها به همراه دارد. 
لازم است تحقيقات بيشترى انجام شود. اگرجه يك كار

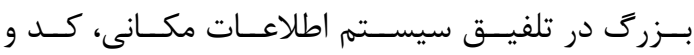
فتوگرامترى انجام شده است و جنـين سيسـتمهـــيى بــهـ

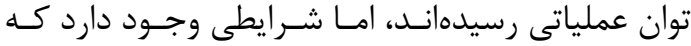
مشاهدات غير فتوگرامتريك براى يشتيبانى از دادههاى

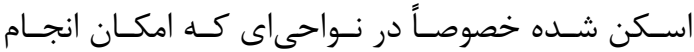
عكسبردارى استريو وجود ندارد، مورد نياز است.

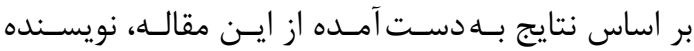

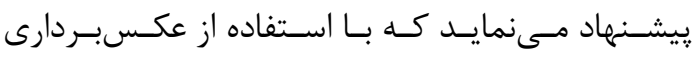
ديجيتالى، رقومى نمودن و يا اسـكن از ســوح اجسـام

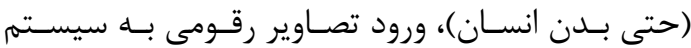
ارائه شده در اين مقاله و يردازش اطلاعات به مـدلهـــاى سطحى سلبعدى كه مورد نظر هدف است، دستيافت. سيس با بهرهبردارى مناسب از ساختار دادههاى رقـومى سـى استخراجى در راستاى هدف مشخصش شده كام برداشـت. در اين يزوهش، هدف نهائى مدل كردن مجسمه يـادبود

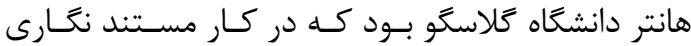
دقيق و حفظ آثار باستانى مورد نظر باسـتان شناسـان و

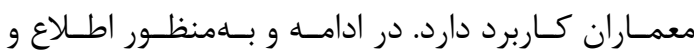
ييشخيرى از حوادث و خطراتى كه دركمين يـك شـى

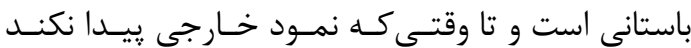

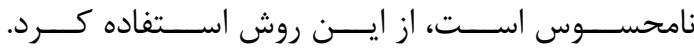

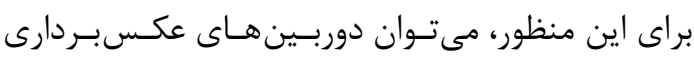

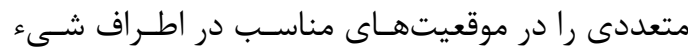
مورد نظر مستقر و ثابـت نمـود تـا بـهـــور خودكـار در

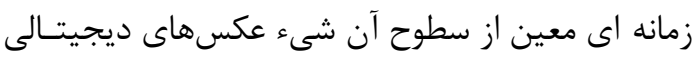

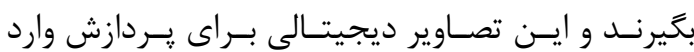

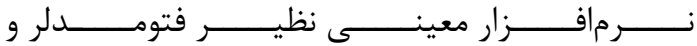

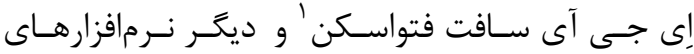

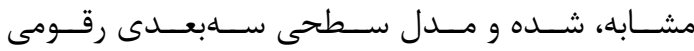
بلهوجود مى آيد. دادهاى استخراجى از مدل ساخته شده

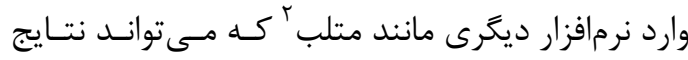

\footnotetext{
${ }^{1}$ Agisoft Photo Scan

${ }^{2}$ Matlab
}

شناخته شـدهــرين برنامـههــاى علـوم فتـوخرامترى در زمينههاى خاص خصوصاً معمارى و باستانشناسى شده

است.

\section{II - يثوهش بيشتر و تحقيقات ييشنههادى}

در سال هاى اخير، ييشرفت فراوانى در فناورى اطلاعـات

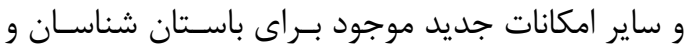
معماران در راستاى كاهش هزينهها و افزايش اثربخشى

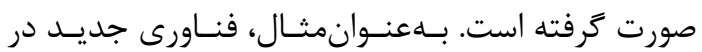

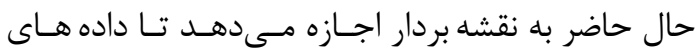

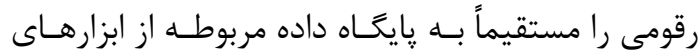

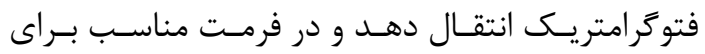
مــديريت و تفســير دادههــاى ســابعــدى در يكـى از

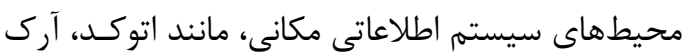
جى آىاس و غيره بهره برد. سيسم

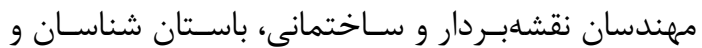

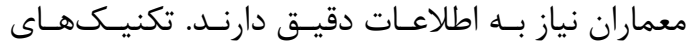
فتوگرامترى رقومى برد كوتاه به كمك ابزارهـاى دقيـق

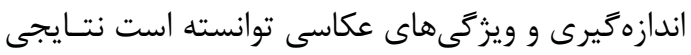
با دقت f ميلى متر توليد نمـوده و بـا بايخـانى اطلاعـات به روز، يك سيستهم اطلاعاتى مكانى ايجاد كند. ايـن بـــ

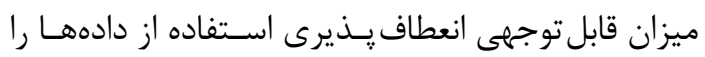
افزايش مى دهد، بهطورى كه مىتوان آنها را در بسيارى از اشكال مختلف ازجمله خروجى به صورت ترسيم و يـا بلهعنوان مدل سلبعدى در محيط اتوكد ترجمه و تفسير به تكنيكهاى فتوگرامترى رقومى سهمى بسـيار مهـم در

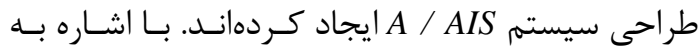
ييشرفت سريع كـهـه در تحقـق دادههـاى رقـومى در هـ سال كذشته اتفاق افتاده است، مىتوان پيش بينى كـرد كه دادههاى حاصل از دوربينهاى ديجيتـالى، اطلاعـات

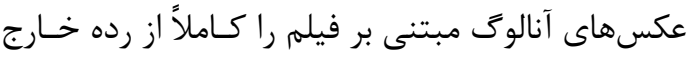
خواهد كرد. با وجودى كه اين تحقيق برخى از تجربيات رادر مورد امكان مدل كردن جهـرههـا و تجسـم اشـياء معمارى را ارائه مى دهد، اما براى توسـعه اثربخشىى آن، مورن 


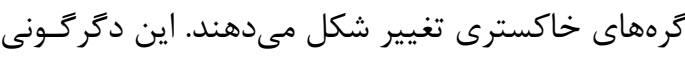

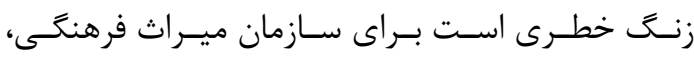

$$
\begin{aligned}
& \text { صنعت، يزشك معالج و غيره (حسب مورد)، كه مى تواند }
\end{aligned}
$$

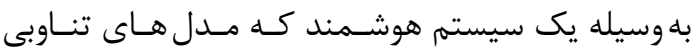

$$
\begin{aligned}
& \text { تشكيلشده را رصد و مقايسه مى كند، نواخته شود. }
\end{aligned}
$$

[1] Brunet et al., Octree Representation in Solid Modelling: In Progress in Computer Graphics, G. Zobrist (Ed.), Abblex Publication Company, 1989, pp. 164-215.

[2] Dallas, Architectural and Archaeological Photogrammetry, Chapter 10 in Close Range Photogrammetry and Machine Vision, K. B. Atkinson (Ed.), Whittles Publishing, 1996, pp. 283-302.

[3] D'Apuzzo, Digitization of the Human Body in the Present Day Economy, Videometrics VIII, proces. of SPIE-IS \& $\mathrm{T}$ Electronuc Imaging, SPIE Vol 5665, San Jose, USA, J. A. Beraldin, S. F. El-Hakim, A. Gruen and J. S. Walton (Eds.), 2005, pp252-259.

[4] Eos Systems Inc., PhotoModeler User Manual, Version 4.0, Canada:Eos Systems Inc, 2000.

[5] Foley et al., Introduction to Computer

$$
\begin{aligned}
& \text { حاصله را به روش ساختار دادههاى درخت هشتـت تـايى ديى }
\end{aligned}
$$

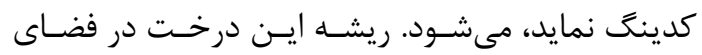

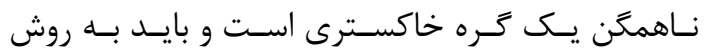

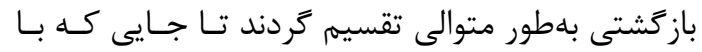

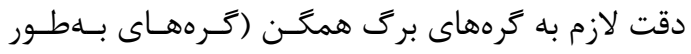

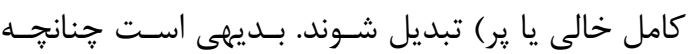

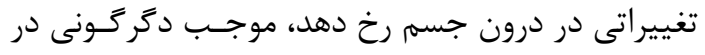

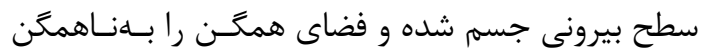

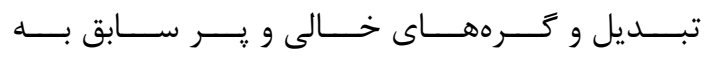

$$
\begin{aligned}
& \text { مراجع }
\end{aligned}
$$

Graphics, Addison-Wesley Publishing Company, 1990.

[6] Mackie, The University of Glasgow, 14511951, Jackson, Son \& Company, 1954.

[7] Sinning-Meister et al., 3-D City Models for CAAD-Supported Analysis and Design of Urban Areas, ISPRS Journal of Photogrammetry and Remote Sensing, Vol. 51, 1996, pp. 196-208.

[8] Watt, D., Brown, D., 2001. "Java Collections: An Introduction to Abstract Data Types, Data Structures and Algorithms", John Wiley.www.amar.org.ir, Statistical Centre of Iran. 


\title{
The Proposed Algorithm for Modelling of Ancient Monuments and Cultural Heritage by using of Hyperspectral Images Data and Digital Terrestrial Photogrammetry
}

\author{
Seyed Yousef Sajjadi ${ }^{1}$
}

1- Assistant professor , Dep. Of Surveying Engineering, Tafresh University

\begin{abstract}
Geographical Information System (GIS) represent a highly relevant branch of information technology. GIS support the geospatial data import from a variety of sources, including imagery. An appropriate environment for providing the spatial information needed by architects working with historic buildings and archaeologists might be soft-copy photogrammetry coupled with, or linked to, GIS, forming an Archaeological/Architectural Information System (A/AIS). A reason for this relativity is simplicity of digital photogrammetry procedures, widespread knowledge and understanding of certain off-the-shelf GIS packages and the scarcity of personnel and equipment capable of performing hard-copy photogrammetric tasks.
\end{abstract}

Key words: 3D Modelling, Photography, Digital Photogrammetry, GIS, AutoCAD, A/AIS

Correspondence Address : Photogrammetric Group, Department of Geomatics, School of Civil Engineering, University of Tafresh, Tafresh, Iran. Tel : +98 8636227659

Email: sajjadi@tafreshu.ac.ir 